NBER WORKING PAPER SERIES

UNION EFFECTS: WAGES, TUFNOVER,
AND JOB TRAINING

Jacob Mincer

Working Paper No. 808
NATIONAL BUREAU OF ECONOMIC RESEARCH 1050 Massachusetts Avenue
Cambridge MA 02138

Noverniber 1981

Research was supported by a National Science Foundation grant SES-7812878 A02 to the NBER, and by a Sloan Foundation grant to Columbia University's Workshop in Labor Economics. The research reported here is part of the NBER's research program in Labor Studies. Any opinions expressed are those of the author and not those of the National Bureau of Economic Research. 
Union Effects: Wages, Turnover, and Job Training

\begin{abstract}
This study explores the existence of a net union premium and of the extent of rationing by quality of the resulting excess supply. The net union premium was estimated by relating changes in wages to changes in union status of the same worker in longitudinal panels (NLS and MID), and by two cross-section wage level regressions, a "prospective" and "retrospective" which permit more direct observation of selectivity in hiring. Over a half of the cross-section differential of over $20 \%$ for the "same" (standardized) worker is a net union rent and much of the rest reflects a quality adjustment in hiring, as measured by wages. This conclusion was less reliable for older workers.

Subsequent analysis explores the effects of successful union wage pressure on: quit rates, fringe benefits, wage profiles, and training.

The reduction in quit of union joiners depends on the size of the net wage premium. Quit rate differentials are also positively related to the gross, cross-section wage differentials within groups of workers, classified by location and occupation, less so by industry.

In Section 4, it is hypothesized that the imposition of larger fixed labor costs (such as fringes) helps to deter employers from preferring reductions in hours to reductions in men, and it helps to stabilize employment in the face of fluctuating demand, by a more frequent use of overtime and of temporary layoffs in the union sector. This hypothesis links the size of fringe benefits to the union wage gain. An analysis of firms in 70 industries confirms this link.

Union pressure is exerted on the whole tenure profile of wages. The explicit linking of wage levels to seniority reduces incentives for worker investment in general (transferable) training. The total volume of training is indeed reported to be smaller in union jobs, and this is consistent with the flatter profile.
\end{abstract}

Jacob Mincer
Economics Department
Columbia University
International Affairs B1dg. - Rm. 809
New York, New York 10027

(212) 280-3676 


\section{Union Effects: Wages, Turnover, and Job Training}

\section{Introduction}

Growing numbers of empirical studies confirm the prevalence of the following features which distinguish unionized from non-unionized labor markets: (I) Higher wages (2) A larger shaie of fringe benefits in total compensation (3) Lower quit rates and lesser turnover, and (4) Flatter age-profiles of wages. These findings appear to hold both in the aggregate, as when more unionized industries are compared with less or non-unionized, and in micro-data where a variety of variables are used to control for personal and, less frequently, firm characteristics which might affect these differences.

Traditionally, economists have been concerned with the relative wage and much less the employment impact of unionism, just as they have been concerned with price-quantity impacts of product monopolies. On the other hand, students of industrial relations tend to emphasize non-wage aspects of unionism in the work setting. Some time ago (1958) H.G. Lewis dichotomized aspects of unionism into "monopolistic" and "competitive". In the first category are the imposition of wages above competitive levels, either by union restriction of supply or by threats of strikes implicit in collective bargaining. In the second are all those activities of unions and work rules espoused by unions which need not be inconsistent with competitive wage-setting. However, these "two faces" of unionism do not correspond to wage and non-wage aspects of unionism: union induced nonwage conditions may also impose higher costs on employers, inconsistent with competition. Conversely, union-nonunion wage differentials need not reflect monopoly rents,

* The comments of $\mathrm{H}$. Gregg Lewis have been most helprul. Thanks are due also to Reuben Gronau, Nori Hashimoto, and John Pencavel. I am grateful to Robert shakotko for helpful discussions and for the supply of data on firms; to Dan Friedlander for able and conscientious research assistance; and to Annette Fisch for competent and devoted secretarial
help. 
but may be merely compensatory, reflecting a faster and more regimented pace of work (Duncan and Stafford, 1980) or higher quality of workers in unionized jobs. The wage-push hypothesis receives almost little or no attention in analyses of other features of unionized labor markets listed in the first paragraph. Thus with "voice", as a substitute for "exit", unionized workers quit less frequently than others. With longer expected stay, the probability of receiving initially non-vested pensions increases, hence larger pensions (a major part of fringe benefits) are demanded by union workers. Other explanations of larger union fringes run from union democracy which favors the older worker to union management of pension funds as an instrument of power. Finally, the flatter union wage profile is seen as a result of union egalitarian or bureaucratic compression of the wage structure.

Although some or all of these hypotheses may be valia, it is possible to view the union wage pressure as a source, if not necessarily an exclusive one of all of the features I have enumerated. It is the purpose of the present study to test this proposition empirically.

\section{Union Wage Gains}

Before I proceed to explore the effects of union wage pressure on turnover, fringe benefits, and wage profiles, it is necessary to establish that unions indeed succeed in pushing their wages above competitive levels. A large literature (see review by Parsley, 1980) answers this question positively, by observing a differential in favor of union members after controlling for a large number of worker personal characteristics in wage level regressions. However, unmeasured differences in labor quality may still be responsible for part or all of the wage gap. The question is whether, indeed, the same worker, and not merely his statistical surrogate, receives higher wages in union than in nonunion employment. 
If the existence of a net union wage gain is confinmed in this fashion, we would expect its size to be smaller than the cross-sectionally observed union wage differential. This is because above equilibrium wages imply queues on the supply side which must be rationed. ${ }^{1}$ only in the case of probabilistic rationing ("first come, first served") and of rationing by price (union dues) or by discrimination and nepotism would the observed net wage gain equal the gross wage differential observed in the cross-section. But, employers have incentives to reduce the increase in labor costs imposed by the union by systematic rationing, that is by hiring more productive workers from the queue. The increase in labor costs cannot, however, be completely offset in this fashion partly because the marginal cost of screening for quality is positive and because of technological constraints in the production function. Moreover, where unions have a voice in hiring, as in the closed shop and in union hiring halls, there are no obvious incentives for upgrading of labor quality, and rationing is largely probabilistic. Rationing by price (in corrupt unions) or by discrimination and nepotism is outlawed, in principle, but its existence cannot be excluded.

The empirical analysis described below relies on observing wages received by the same worker before and after his change of union status. This approach was used most recently by Duncan and Stafford $(1980)^{2}$ and, thus far, most comprehensively by Wesley Mellow (1981). Duncan and Stafford observed wage changes of a small sample of union joiners between 1968 and 1971 in the Michigan Panel survey of Income Dynamics (MID), and Mellow in two one-year intervals (1974-75 and 1977-78) in the much larger sample of the Current Population survey (CDS). Iarge data sets, like the CPS sample, are needed to observe adequate numbers of workers who change union status, since their proportion is quite small. An alternative to using the CPS is pooling of the longitudinal samples. Although the annually surveyed samples in the MID and NIS (National Longitudinal Surveys) are much

\footnotetext{
The existence of union induced queues has been inferred in an econometric analysis of Farber and Abowd (1981). 2 Other references are: Brown (1980), Duncan (1979), Chamberlain (1978), Kenny (1978), and Raisian (1981).
} 
smaller than the CPS, their advantage lies in some of the information not available in the CPS. Especially useful in this context is information on job mobility and job tenure.

In the work to be described I pooled the MID sample in order to relate annual changes in wages of white men over the 10-year period 1968-1978 to changes in their union status. Since the NLS panels contain information on union status in the years 1969 and $1971,{ }^{1}$ I utilized this single interval for the same analysis on the two NLS panels of young white men (who were 17-27 years old in 1969) and older white men (who were 48-64 in 1969). The MID contains all ages, but as in the NLS, I limited the sample to non-students and to a maximum age of 64. For (partial) Comparability with the NLS, I also stratified the MID panel into young (less than 30) and older $(30-64)$ subsamples.

${ }^{1}$ I did not use the less adequate telephone survey of 1970 which also contained questions on union status. 
The statistical analysis relies on wage functions, where the dependent variable is the logarithm of hourly earnings, and the independent variables are education (Ed), experience $(x)$ and its square $\left(x^{2}\right)$, length of job tenure (T) and its square $\left(T^{2}\right)$, marital status (Mar), health status (H1th), local (Lun) and national unemployment rate (Nun). These are the "standardizing" variables. The main focus is on the additional (dummy) variables $U i j$, where $i$ and $j$ index the first and second period, and have values $(0,1)$, 0 denoting non-union status and 1 , union membership. Thus Uoo means non-union both years, $\mathrm{U}_{01}=$ union joiner (between the first and second survey), $U_{10}=$ union leaver, and $U_{11}=$ union stayer. These four union status categories were also cross-classified by mover-stayer status, and for movers by form of separation (quit, layoff) and whether moved within or between industries.

Wage level equations were used separately for the first and second year bracketing the changes. ${ }^{1}$ Both equations contain the same union dummies. Thus in "year 1" equations, the dummies indicate prospective changes (or continuation) of union status, while in "year 2" they indicate recent change. Both are useful in exploring selectivity in hiring. The specification of wage change equations is derived by taking first-differences of the variables in the level equations. Thus the experience variable becomes $\Delta x=1$ for all, and its coeficient enters the intercept, but $\Delta x^{2}$ differs with the level of experience. The tenure variable $\Delta T$ equals 1 for job stayers but becomes negative ( $T$, where $T$ is length of job tenure on the preceding job). Correspondingly, $\Delta \mathrm{T}^{2}$ is positive for stayers, but is negative and equals $-T^{2}$ for movers. Standardization for tenure is important: since wages grow with tenure (experience held fixed), wage change estimates from regressions which omit tenure depend on how long recent movers stayed on the previous job. Put another way, estimates which omit tenure indicate the immediate wage change in moving from one job to another, while the present

In the NLS the first year is 1969 , the second 1971. In the MID the pairs of years are adjacent. 
specification estimates the wage change from the prior to the current job, at comparable tenure levels. This is, clearly, a more appropriate measure of returns to job mobility, or to change in union status.

Although the pooling of ten periods provides an effectively much larger sample of the MID observations, the smaller NLS sample is in some respects superior: fewer observations are lost due to incomplete responses, and hourly wage refers to the current job rather than to the calendar year as in the MID. The NLS also contains an alternative union status definition in addition to union membership (UM), a question on whether the job is covered by collective bargaining $(C B)^{1}$.

In the MID, job and union status changed between surveys, which were taken in the second quarter of each year. Wage changes, however, refer to calendar years. Since we bracketed status changers by adjacent years, if the reported wages are indeed weighted annual figures, they could underestimate the true change by as much as 33\%. We checked on the degree of bias in several periods (1976, 1977, 1978) when the question on wages was asked for the current job. The so estimated bias was on average $21 \%$. The bias could be removed by leaving out two years between "year 1" and "year 2". But this would have eliminated a large fraction of job changers, whose tenure at moving is short. 
Table I shows sample means (i.e. proportions) of the union status categories for the young and old men panels by alternative definition of union status in NLS and in MID. $28.3 \%$ of the young men and $36.3 \%$ of the old men were union members in 1969. A somewhat larger proportion (33.2\% and $39 \%$ respectively) were covered by collective bargaining agreements. Union-nonunion turnover is quite large among the young and much smaller among older job movers. A surprising and somewhat puzzling statistic is the number of union status changers who do not change jobs (firms) -- it is as large as the number of union joiners who are movers among the young and even larger among the old. The preponderance of stayers who are union status changers is even stronger in MID, in which the proportion of all movers appears to be smaller than in the NLS.

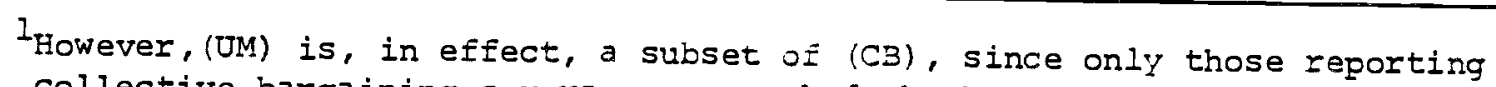
collective bargaining coverage were asked whether they are union members. The (CB) definition is available in MID only for a few periods, so it could not be utilized in the pooled sample. 
Table 1

Samole Proportions in Union Status Categories

NLS and MID

(A) NLS

$\frac{\text { Young Men, } n=1160}{\text { Movers } \frac{\mathrm{UM}}{\frac{C}{\sigma}}} \frac{\frac{C B}{\%}}{\frac{\sigma}{\gamma}}$

\begin{tabular}{l|rr}
$U_{00}$ & 24.3 & 21.9 \\
$U_{01}$ & 4.6 & 4.9 \\
$U_{10}$ & 4.4 & 5.2 \\
$U_{11}$ & 4.4 & 5.7
\end{tabular}

Stayers

\begin{tabular}{l|rr}
$U_{00}$ & 38.6 & 36.0 \\
$U_{01}$ & 4.2 & 4.0 \\
$U_{10}$ & 1.5 & 2.0 \\
$U_{11}$ & 18.0 & 20.3
\end{tabular}

(B) $M I D$

A11, $n=9,987$

Movers

\begin{tabular}{l|r}
\hline$U_{00}$ & 7.3 \\
$U_{01}$ & 1.0 \\
$U_{10}$ & .9 \\
$U_{11}$ & 1.3
\end{tabular}

Stavers

\begin{tabular}{l|r}
\hline$U_{00}$ & 56.8 \\
$U_{01}$ & 2.6 \\
$U_{10}$ & 2.3 \\
$U_{I I}$ & 27.8
\end{tabular}

Age < 30, $\mathrm{n}=3,069$

$52.2 \quad 49.4$ $31.2 \quad 32.7$
$4.2 \quad 4.7$

$2.0 \quad 2.8$

$\begin{array}{cc}\frac{\text { Old }}{\frac{\mathrm{UM}}{3}} & \frac{\mathrm{CB}}{\frac{\mathrm{B}}{3}} \\ 6.5 & 5.9 \\ .8 & 1.0 \\ .5 & .8 \\ 2.6 & 2.7\end{array}$


Although some stayers may become union members, after a short period in the union shop, or by switching jobs within the firm, or by the firm becoming unionized, the figures for job stayers who change union status appear to be inflated by misreporting or misclassification. This is especially likely in the MID samples, where wages of union status changers who are job stayers are about the same (relative to the base group) before and after the change, (see Table 5).

Table 2 presents estimates of the 1969 to 1971 wage changes in the NLS by union change category, net of the other variables (these are shown in Appendix Table AI), classified by mobility status, age, and derinition of union sector (UM: union membership, CB: coverage of wage by collective bargaining agreement). Numbers in Table 2 are regression coefficients, with t-statistics shown in parentheses.

Using point estimates and the union membership criterion, young men who joined unions by changing firms got a $17.6 \frac{3}{3}$ increase in wages, while older men gained 7.4\%. However, by the collective bargaining criterion, the gain was similar for young and old (13.5\% vs. 11.6\%). The figures for the older men are barely significant. The wage changes are adjusted for inflation and are net of the wage change experienced by the base group of non-union stayers. Firm stayers who zeport joining unions show smaller gains, with lesser statistical significance. Although it may be advisable to discount (or ignore?) the estimates for stayers, there is still a question whether the figures for job movers should be viewed as the net union premium: even if they did not join a union, young movers between non-union firms $\left(U_{00}\right)$ gainea 3.5 to $6.4 \%$. IE such gains measure the return on costs of mobility, the net profit of joining unions by moving is reduced to between $7 \frac{\%}{3}$ and $14 \%$ for the young movers, and is comparable for the older union joiners although the statistical reliability of the estimates for the older group is much weaker. 
Table 2

Wage Growth 1969 to 1971 in the NLS

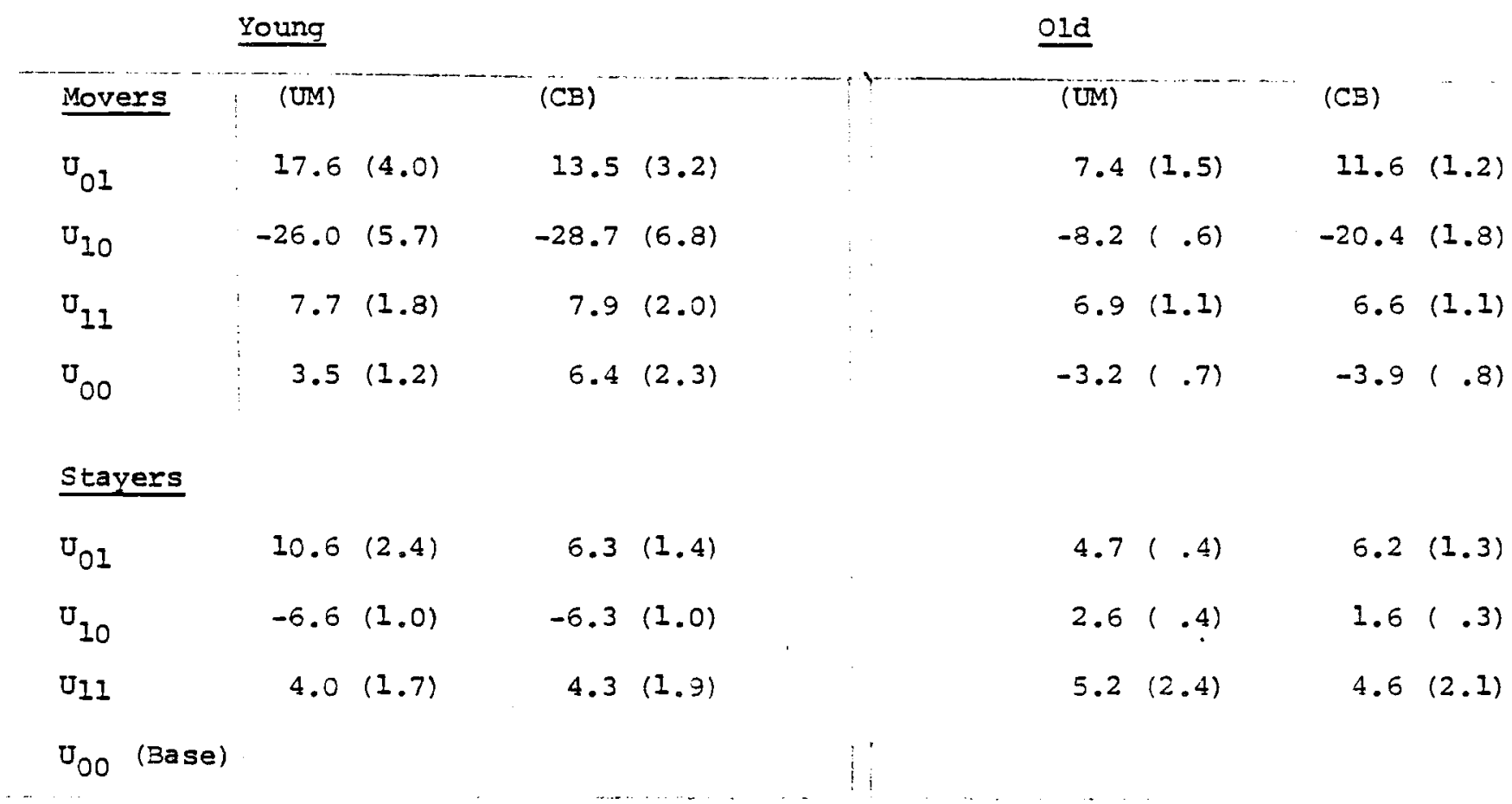


When the movers' separation is distinguished by quit and layoff (see Table $A 3$, upper panel), the gain from joining a union is about the same regardless of manner of separation, though for movers within the nonunion sector $\left(U_{0 O}\right)$ the gain is a positive $5-6 \%$ for quitters and near zero for those laid-off. These distinctions are not perceptible for the older union joiners whose sample further divided into quit and layoff becomes miniscule. However, old non-union movers $\left(U_{00}\right)$ experience zero gains in quitting and significant losses by layoff.

In turn, when movers are distinguished by moves between or within industry (Table A3, lower panel), (at the 2-digit level), gains to young union joiners were observed only for inter-industry movers. They are not significant for within-industry movers, but the latter comprise no more than $20 \%$ of young movers who join unions. Again, no significant differences can be observed in the small samples of older movers.

Movers who left unions (U 10 in Table 2) suffered losses which exceeded the gains of movers who joined unions. The losses were even greater when the separation from the union job was by layoff, and when the move was between industries. Again less confidence should be attached to such findings for the older men. If the loss of union leavers is to be viewed as another measure of the union premium (with a negative sign), it is not clear why it is so much larger than the positive measure. The discrepancy may reflect further sorting by layoff from union firms, but the basis for such speculation is weak.

Table 3 presents estimates of annual wage change equations, pooled over the period 1968 to 1978 in the MID. Only one definition of union status (union membership) is available for all the years. The finaings, coefficients of union dumies, are shown for all ages and for the two age groups, below age 30, and $30-64$, separately. 
Table 3

\section{Annual Wage Growth 1968 - 1978, MID, pooled}

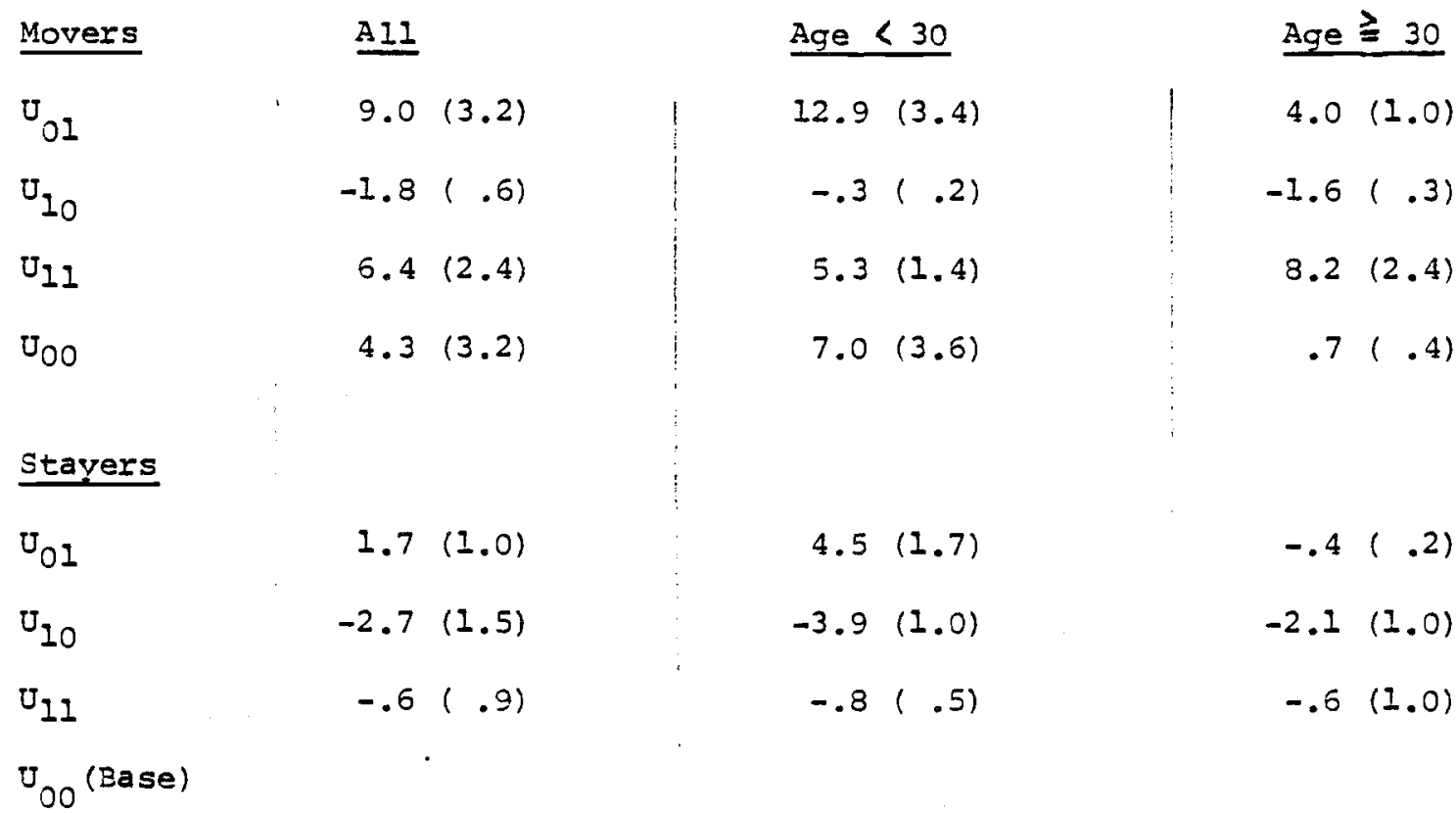


Young men who join the union by changing fims gain about $13 \frac{2}{3}$ in wages; the older men's gain of $4 \%$ is not statistically significant. The average gain for all is 98 . This reduces to $6 \%$ for the young and less than 58 for all, if the union premium is viewed as net of the return to mobility into a non-union job. However, when the moves of union joiners are classified by quit and by layoff, (Table A4, upper panel), the gain by quitting was significantly larger: $19.3 \%$ for the younger and $11.8 \%$ for the older group. The non-union quitters had gains of $12.4 \%$ and $4.6 \%$ respectively. A net premium which would take into account the returns to mobility makes the net differential about $7 \%$ for guitters in both age groups. Again, as in the NLS, the gain for union joiners who are movers shows up in inter-industry mobility.

Compared to the NLS, MID estimates of the average union premium appear to be somewhat smaller. 'A major difference is in the estimate of losses of union leavers: they are larger than the gains of joiners in the $\mathrm{NLS}$, but insignificant in MID. However, the insignificance in the MID sample applies only to the young group. Among those over 30, union leavers who quit gain $12 \%$ while those laid off lose $8.6 \%$. No significant wage changes are observed for persons who did not change jobs. Reported changes of union status in this group are more questionable than in the NLS sample.

To summarize the findings in both the MLS and MID: (1) Estimates of wage changes of union joiners are near $15 \%$ for young $(<30)$ white men and $4-12 \%$ for older men. If gains from (non-union) mobility are subtracted from these estimates, the net union premium is reduced to between $6-24 \frac{7}{5}$ for the young joiners.

(2) The union premiun appears to be larger for the young than for the older men. This is not true if collective bargaining rather than union membership is a criterion (in the NLS). Nor is it true in MID iz union joiners quit from the preceding job.

\footnotetext{
IRecall ( $(. \overline{0}$, above) that MID estimates of wage changes tend to be understated.
} 
(3) The union premium is clear and significant mainly if union joiners quit the preceding job and moved between (2-digit) industries, as 80 \% of them did.

(4) Union leavers lose more than union joiners gain in the NLS. In the MID sample, only union leavers over 30 who were laid off lose as much or more than joiners gain. There is no evidence of losses for the younger union leavers.

\section{Cross-Section Differentials and Selectivity in Hiring}

Tables 4 (for NLS) and 5 (for MID) present coefficients on union status dummies in two cross-section wage regressions, year 1, prior to the change in union status, and year 2 after the change. Thus for job movers the coefficient on $U_{01}$ in the"prospective"regression (year 1) estimates the wage of prospective movers Irom non-union to union jobs (e.g. a coefficient of 1.2 means $1.2 \%$ points larger than the wage of the base group = nonunion stayers). The coefficient of $U_{01}$ in the "retrospective"regression (year 2) estimates the wage on the new union job of these recent union joiners, again relative to the base group in year 2 .

If the existence of a union premium induces employers to select more productive labor, we would expect prospective union joiners to have higher wages in the prior, nonunion job than other nonunion workers. We have to be careful, however, to compare wages of new hires into union jobs with wages or new hires into non-union jobs: employers select among new hires. Thus the difference between the coefficients of $U_{O 1}$ and $U_{0 O}$ of job movers in the prospective regression (year 1) measures the upgrading in hiring into union jobs. Although union joiners had a prior non-union wage about the same as the base group of nonunion stayers, their wages were significantly higher (about 10\%) than the prior non-union wage of new hires into non-union jobs. This selectivity differential appears to be similar for the young and old NLS samples and is roughly comparable in size (a bit smallen) to the net union premium estimated from

the wage changes. 
Table 4

\section{Wage level equations $N$ LS}

$1969=$ year 1

Young

old

Movers

(UM)

(CB)

(UM)

(CB)

$U_{01}$

$1.2(.3)$

$-2.6(.6)$

$-3.4(.2) \quad-4.5(.7)$

U10

$20.8(4.6)$

$20.7(4.9)$

$\mathrm{U}_{11}$

$33.3(7.4)$

$27.2(6.6)$

$\mathrm{U}_{00}$

$-9.7(4.0)$

$-10.2(4.0)$

$3.1(.2) \quad-2.9(1.0)$

$42.9(6.1) \quad 43.7(6.4)$

$-11.6(2.6) \quad-11.0(2.3)$

\section{Stayers}

$\mathrm{U}_{01}$

$\mathrm{U}_{10}$

$6.1(1.3)$

$11.7(1.6)$

$7.2(1.5)$

$6.9(1.0)$

$16.0(6.2)$

U 11

UO (Base)

$1971=$ year 2

Movers

$U_{01}$

$22.0(4.0)$

$14.4(2.6)$

$\mathrm{U}_{10}$

$1.8(.3)$

$43.4(7.9)$

$-3.2(1.6)$

U०

\section{Stayers}

U 01

$-1.5(.2)$

$-2.8(.3)$

$20.0(7.2)$$$
38.7(7.6)
$$$$
-.5(.2)
$$

$$
-9.8(1.8) \quad-9.4(1.8)
$$$$
-6.4(.8) \quad-6.3(1.0)
$$$$
.2(.1) \quad .3(.2)
$$

$\mathrm{U}_{\text {IO }}$

$U_{11}$

U
$3.7(.5)$

$19.6(7.0)$

$$
14.1(2.6)
$$$$
3.7(.5)
$$

$-1.5(.3)$

$-2.8(.3)$

$4.5(1.6)$

$$
\begin{array}{rrr}
7.6(.5) & 9.5(.8) \\
.2(0) & -27.0(2.0) \\
55.5(7.6) & 56.2(7.1) \\
-9.2(1.6) & -8.6(1.5)
\end{array}
$$


Table 5

Wage level estimates, MID - Pooled

Year 1

A11

Age $<30$

Age $\geqq 30$

Movers

U 01

$\mathrm{U}_{10}$

$\mathrm{U}_{11}$

एoo

Stayers

U 01

U10

$\mathrm{U}_{11}$

$-12.9(3.9)$

$-8.6(2.3)$

$17.6(5.6)$

$-16.0(11.3)$
-6.2 (1.8)
$2.2(.5)$
$21.5 \quad(4.4)$

$-14.1(7.5)$

$-24.2(3.8)$

$-17.2(3.0)$

$13.7(3.2)$

$-15.2(7.2)$

U 00 (Base)

Year 2

Movers

UoI

$-1.4(.4)$

$13.2(2.8)$

$1.0(.2)$

$-4.7(1.1)$

$26.1(7.4)$

$32.7 \quad(6.2)$

$-4.9(2.0)$

$-14.2(8.9)$

Stayers

UI

$5.3(2.1)$

$1.9(.7)$

$10.7(2.3)$

$\mathrm{U}_{10}$

$16.7(17.3)$

$3.5(.3)$

$\mathrm{U}_{11}$

Uoo (Base)
$3.7(1.2)$

$1.8(.5)$

$-10.5(1.8)$

$-2.6(.4)$

$23.7(5.7)$

$-15.2(6.5)$

14.8 (13.1) 
The comparison of coefficients on $\mathrm{U}_{O I}$ and $\mathrm{U}_{00}$ of MID movers (Table 5) in year 1 yielas the conclusion that workers newly hired into union jobs had, on average, higher wages on the preceding job in the non-union sector than nonunion workers hired into non-union jobs. The difference is smaller in the Michigan Panel than it was in the NLS. But this is a result of two opposite differentials by age. The young workers hired into union jobs had $8 \%$ higher wages than the prospective non-union hires, a figure comparable to the selectivity differential estimated for young NLS workers. However, the older group of new hires (30+) had lower wages than the comparison group of non-union hires. Inspection of year 2 wages of new hires in their new jobs shows that the wage differential between non-union workers (in year 1) who moved to union and non-union jobs respectively (in year 2) has just about doubled (roughiy from 10 to 208) between year 1 and year 2 in both NLS and MID samples of young workers. Thus the union-nonunion differentials (among new hires in year 2) reflect selectivity in hiring and a net union wage premium in about equal measure. For the older worker the results are mixed: In the NIS the union-nonunion dirferential among new hires (year 2) more than doubled compared to year 1 , while in the MID the differential changed from negative in year 1 to positive in year 2 .

A sharper view of these comparisons is shown in Table 6. A little arithmetic is helpful in inspecting the table. First, it is clear that the increment in the wage differential between union and non-union new hires from yeax 1 (on the old jobs, both non-union) to year 2 (on the new jobs, one union, the other non-union) is in principle, ${ }^{1}$ equivalent to the wage change regressions estimate of the union wage premium, net of selectivity, since:

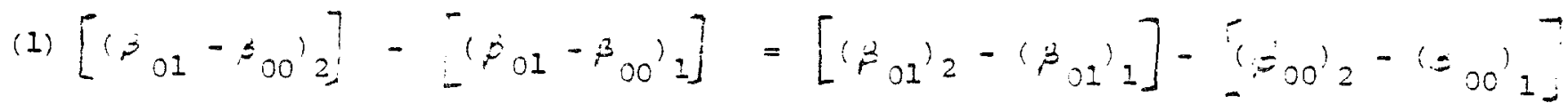
In practice, the estimates differ largely because of a aiffering structure of errors in levels and in changes. 
Table 6

\begin{tabular}{|c|c|c|c|c|c|c|}
\hline & & $\begin{array}{l}\text { Wage Differentials } \\
\text { New hires } \\
\left(G_{01}-\overline{F O O}_{2}\right)_{2}\end{array}$ & $\begin{array}{l}\text { Selectivity } \\
\text { in hiring } \\
\left(\hat{F}_{\left.01-1_{00}\right)_{1}}\right.\end{array}$ & $\begin{array}{l}\text { Implicit } \\
\text { Wage Gain } \\
(1)-(2)\end{array}$ & $\begin{array}{l}\text { Estimated } \\
\text { Net Gain } \\
\text { of joiners } \\
\text { (Tables } \\
2 \& 3)\end{array}$ & $\begin{array}{l}\text { Wage Difierential } \\
\text { of Stayers }\end{array}$ \\
\hline & & (1) & $(2)$ & (3) & (4) & (5) \\
\hline \multicolumn{7}{|l|}{ NLS } \\
\hline Young & (UM) & 25.2 & 10.9 & 14.3 & 14.1 & 20.0 \\
\hline & (CB) & 14.9 & 7.6 & 7.3 & 7.1 & 19.6 \\
\hline \multirow[t]{2}{*}{$01 d$} & (UM) & 16.8 & 8.2 & 8.6 & 10.6 & 4.5 \\
\hline & (CB) & 18.1 & 6.5 & 11.6 & 15.5 & 3.4 \\
\hline MID & (UM) & & & ; & & \\
\hline Young & & 18.1 & 7.9 & 10.2 & 5.9 & 22.4 \\
\hline older & & 4.7 & -9.0 & 13.7 & 3.3 & 14.8 \\
\hline AII & & 12.8 & 3.1 & 9.7 & 4.7 & 16.7 \\
\hline
\end{tabular}


The $\beta_{i j}$ are the regression coefficients on the respective union dummies $U_{i j}$. The first term on the left hand side is the cross-sectional union-nonunion wage differential for new hires, the second term measures upgrading in union hiring, and the right hand term is the implicit union wage premium $\left(\Delta \beta_{01}-\Delta \beta_{0 O}{ }^{\prime}{ }^{\prime}\right.$ with returns on costs of mobility netted out. ${ }^{1}$

The interpretation expressed on the left hand side of (1) justifies the use of the second term on the right hand side: Emphasis on new hires coming from the nonunion sector; where wages may be assumed to reflect the marginal value product, justifies the netting out of returns to mobility of workers moving within the non-union sector only.

Column(1) of Table 6 shows the cross-section union non-union differential for new hires. Column (2) shows the selectivity (upgrading) differential, which is a component of the union-nonunion wage gap (1). Column (3) is the difference between (1) and (2), the implicit net union wage premium obtained by new hires. For comparison, Column (4) shows the net union wage premium estimated from the wage-change regressions, and Column (5), the cross-section union-nonunion wage differential among stayers (coefficients of $\mathrm{U}_{11}$ of stayers in year 2), which comes closest to the usual regression estimates of the union-nonunion differential in the cross-section.

Judging by the first two columns of Table 6, selectivity in hiring, as measured by prior wages, accounts for almost one half of the union-nonunion wage differential among young new hires in the NLS, but less in the MID. The time-series estimates of the net wage premium (col. 4) are comparable to the implicit cross-section estimates (col. 3) in NLS, but they are smaller in the MID. For the older group in MID, selectivity into the union (col. 2) appears to be perverse, that is negative. 
The analysis sumarized in Table 6 contains several innovations: (1) It relies on estimates of wage changes of workers whose union status changes as they move between firms. This is because reports of changes in union status while staying in the firm appear to be less reliable and show small or no effects. Previous studies which do not contain information on job mobility, therefore, probably attenuate the effects of unions on wages. (2) Information on mobility also permits more direct estimates of selectivity in hiring, as shown in col. 2 or Table 6 . (3) Finally, the information on tenure makes possible estimates of gains from mobility as upward shifts of the whole tenure profile of wages from the old to the new job. Usually observed instantaneous wage changes may be negative, as is often found, but the longer run effects obtained in the present analysis are more likely to be positive. ${ }^{1}$

As to numerical results, it appears that estimates of net union gains in wages, as seen in new hires, range from 7 to $15 \frac{\gamma}{\gamma}$ in the NLS and from 3 to $14 \%$ in the MID. Since the latter is biased downward, upward adjustments would gut the central tendency of both NLS and MID a little over 10\%. Selectivity accounts for almost as much in the NLS and the young workers in MID, but not so in the over 30 group in MID.

${ }^{1}$ Even though superior as measures of gains from mobility, the shifts in tenure wage profiles are not fully commensurate with gains in present values. It can be shown that in order to secure the same gain in the present value of wages, moves after longer tenure require a larger shift in the tenure profile on the new job. This was confirmed empirically by positive and significant coefficients on a job change $x$ prior tenure interaction variable in the wage change estimates (not included in the present stucy). 


\section{Turnover in Union Employment}

If the wage received in union employment exceeds the worker's opportunity wage in non-union employment, he is less likely to quit a union job than a nonunion job.

As Table 7 indicates, guit rates in the urion sector are about half as large as in the non-union sector for young workers and are about one third as large for men over 30 (in MID), and one seventh for men over 48 (in NLS). The aifferences are smaller for separations, since layoffs are somewhat larger in the union, at least in the NLS.

Although one third of the white male workers are unionized (somewhat less among the young), less than $10 \%$ of non-unionized job seekers find employment in the union sector, while a half of the young and two-thirds of the older unionized job movers find employment in the union sector. Since these statistics apply to "unstandardized" workers, they may reflect differences in tastes and in geography, industry, and occupation. At face value, at any rate, the differences are consistent with our Findings: non-union workers could get a bigger wage gai n by moving to union jobs, but are evidently prevented by fewer vacancies and nonprobabilistic rationing (stricter hiring standards, nepotism, etc.) resulting from the wage premium in the union sector. Union workers, however, can gain from mobility within the union sector, but face a wage loss when they leave the union sector. (Tables 2 and 3 above). Thus they tend not to leave the firm unless there is a good chance of landing another union job. ${ }^{1}$

If the existence of grievance procedures ("voice" instead of "exit") were the major force that ties groups of workers with similar preferences to a firm, we would expect lesser guit from firms with such labor relations. But, in the absence of a wage premiun in unionized fims, those who separate from suci firms would be largely indifferent whether they moved to a union or non-union fim. It is, incidentally, not clear why grievance procedures cannot exist need be or less effective in non-unionized fims, i= reduction in turnover reduces labor costs. 
Table 7

Turnover Rates ( 3 ), by Union Status and Age

NLS

(a) Quits Young

NU

U

(b) Iayofis

NO $\quad 13.5 \quad 5.0$

U

17.7

(c) Separation

$\begin{array}{lll}\text { NU } & 40.2 & 11.5 \\ \text { U } & 32.0 & 7.9\end{array}$

MID

$\begin{array}{ll}\text { Age < } 30 & \text { Age } \geqq 30 \\ 14.6 & 4.7 \\ 7.5 & 1.7\end{array}$

7.0

3.0

6.6

2.7

21.6

7.7

14.1

4.4 
If unionization reduces job mobility, this reduction should be observed on the same individual by comparing his mobility before and after joining a union firm. And if the wage premium gained by moving to a union firm matters, the reduction in mobility should be greater the greater the wage gain.

According to Table 8, young NLS men who joined unions between 1969 and 1971 have prior quit frequency (in 1967-1969) which was not smaller than the quit of other nonunionized workers at that time. I This is based on regressions with quit as a dependent variable $(0,1)$ and 1969 values of the same standardizing variables as used in the wage level regressions. However, the frequency of guit was lower by about $13 \%$ points in $1971-1973$ after joining a union (coefficient of $\mathrm{U}_{01}$ ) in the interval 1969-1971. This reduction is as large as the unstandardized cross-section difference in Table 7. In 1971-1973 union stayers (U11 in 1969-71) had about the same low guit rates as union joiners. ${ }^{2}$

No significant results were obtained for the older NLS men who joined unions, but union stayers had significantly lower quit rates than non-union workers both in 1967-1969 and in 1971-1973.

\footnotetext{
IFor a similar finding, based on other data, see Freeman (1980).

${ }^{2}$ Recal1 that union status was not reported in 1967, so many of the young union stavers in 1969-71 were likely to have been joiners in 1967-69.
} 
Table 8

Quits and Layofis, Before and After

Change in Union Status, NLS

$1967-69$

\begin{tabular}{lll} 
Quits & Young & Old \\
\hline$U_{01}$ & $-1.8(.9)$ & $+.9(.4)$ \\
$U_{10}$ & $2.9(.6)$ & $-.8(.2)$ \\
$U_{11}$ & $-4.4(1.5)$ & $-2.2(1.7)$
\end{tabular}

Layoffs

UO1

$\mathrm{U}_{10}$

$\mathrm{U}_{11}$

$\begin{array}{rrr}6.0(1.2) & 3.4(1.1) \\ 16.5(3.2) & 7.8(1.8) \\ -9.4(3.3) & -.7(.5)\end{array}$

1971-73

Young

Old

$\begin{array}{lll}-12.7(2.8) & -1.1(.5)\end{array}$

$\begin{array}{lll}-4.9(.9) & -2.3(.8)\end{array}$

$-16.4(5.2) \quad-2.7(2.7)$

$\begin{array}{rrr}10.3(2.7) & -1.0(.4) \\ 4.8(1.1) & 3.6(.9) \\ 4.1(1.6) & 2.6(1.9)\end{array}$


A comparable analysis was performed on the Eull MID sample (including movers and stayers) using all ages and changes in guit $(\triangle Q)$ as the dependent variable which assumes values $(-1,0,+1)$. Again, the standardizing variables were the same as in the $\Delta$ In wage equations. The results are shown in col. (1) of Table 9.

Union joiners experienced significant reductions in quit rates compared to all other groups. Larger wage gains (for all movers and stayers) also reduced quits in the next period. Here we do not distinguish wage gains of union joiners from those of everyone else.

To observe this distinction we restricted the sample to job movers (about two-thirds of the sample had at least one move during the 10-year panel period). We constructed a mobility index (M), which is a count of numbers of firms in which the person worked up to the current job (i.e. number of separations +1 ) divided by the time interval over which mobility was recorded. The denominator of the index is the interval since entry into the labor force, or since 1958, if entry into the labor force was before this date. Wage changes associated with job moves were recoxded separately for union joiners and for others between 1968 and 1973, and their effects estimated on the change in $M$ (and in In M) between the move and 1978, the last year of the panel.

The numerator of the mobility rate includes permanent layof Es in addition to quits, but is dominated by quits. We could not restrict the index to quits, since the pre-1968 mobility is reported as separations. However, as Table 8 showed, although (permanent) layoifs are somewhat larger in the union sector in the NIS, they are not larger in the MID sample. But, even in the NLS differences in separations are dominated by differences in quits. 


\section{Table 9}

Changes in Quit Related to Changes in Union Status and in Wages (MID)

Changes in Quits

(Full Sample)

$\Delta Q$

\begin{tabular}{|c|c|c|}
\hline$U_{01}$ & -6.1 & $(3.5)$ \\
\hline$U_{10}$ & .7 & $(.4)$ \\
\hline$U_{11}$ & 1.2 & $(1.3)$ \\
\hline$\Delta I n W$ & -4.9 & $(3.4)$ \\
\hline
\end{tabular}

Changes in Mobility Rates

(Sample restricted to movers prior to 1974)

$\Delta I n M \quad \triangle A M$

$U_{01} \quad-.24(4.4) \quad-.01(.3)$

$\Delta \operatorname{lnW}_{01} \quad-.27(2.0) \quad-.20(2.4)$

$\Delta \operatorname{lnW}_{00} \quad-.05(1.7) \quad-.07(1.6)$ 
A preliminary cross-section analysis (Table $\mathrm{A5}$, panel (a)) showed that the mobility rate ( $M$ and $I n M$ ) declines with experience in a decelerating fashion, is reduced by education, marital status, union status, and by economy wide unemployment.

The dependent variable ( $\Delta M$, or $\Delta I n M$ ) in col. 2 and 3 of Table 9 is the difference between the index in 1978 and the first move observed between 1968 and 1973 (inclusive) for non-union people (for most of them this was not the first move,since they moved also before 1968) or the move at which they joined a union. The union dummy $U_{O L}$ distinguishes union joiners from non-union movers and wage gains of joiners $\left(\Delta \mathrm{ln}_{01}\right)$ are distinguished from wage gain of nonunion movers. The standardizing variables are in the form of differences between 1978 and levels at the time of the move. Dumies were added to account for entry into the labor force before 1968, and 1958, and years observed in the panel.

The results show that union joiners reduce their mobility more the larger the wage gain fron joining a union. A similar, but much smaller, and barely significant, effect is observed for wage gains of movers in the non-union sector. This is true whether the index or the changes in wages are logarithmic or arithmetical.

The weak effect of an episode of mobility among non-union jobs is not surprising: unless the rate of return on the cost of moving is unusually high, there are no disincentives to future job search. However, the larger the wage premiun for union joiners the greater the potential loss from future mobility. This reasoning applies nore clearly to quit behavior, but the effects on total separations, if weaker, are similar. 
Whether mere unionization without a wage premium produces a reduction in mobility is not as clear in Table 9. The union dumm has a strong effect on the change in the logarithmic, but not arithmetical, mobility index. It is also strong in Col. (1) where the wage gain of union joiners was not separated from others. Undoubtedly it represents a response to other union benefits, in fringes and in working conditions, including the more certain advantages of seniority. Nevertheless, our findings support the inference that the union wage gain is not merely a compensatory differential for quality of labor, or costs of mobility, or for inferior conditions in union jobs. Union rents appear to be real, although relatively small (closer to $10 \%$ than to $20 \%$ ).

Although cross-section union-nonunion wage differentials (gross) overstate the size of the (net) union premium, it may be useful to explore their effects on differentials in quit rates in the cross-section, on the assumption that the gross and net wage differentials are positively correlated. Again the purpose is to find out whether it is not merely union-status but the size of the differential that affects mobility.

The companion analysis whose reults are shown in Table 10 exploits the large size of the MID panel in another way: we explore whether union-nonunion wage differentials affect quit rates within, alternatively, industries, regions (states), and occupations. The analysis proceeds in two steps: first we added industry (or state, or occupation), union, and industry $x$ union membership dumies to the cross-section wage function. The coefficients of the cross-product dummies $\left(\beta_{i}\right)$ are estimates of within-group union-nonunion (relative) wage differentials (estimates shown in Table $A 6$ ). In the second step we included industry (or other groups), and a union dunmy as well as its cross-product with the estimated union-nonunion wage differentials ( $\beta_{i}$ from the wage regressions) in quit regressions. 
Table 10

Quit Differentials within Groups

$\begin{array}{llcc} & & M I D, 1968-1978 \\ \text { Grous } & & & \mathrm{U} \times \beta \\ \text { Industry } & \underline{U} & .002(.1) \\ \text { State } & -.032(3.5) & -.080(1.8) \\ \text { Occupation } & -.024(3.0) & -.21 \quad(4.1)\end{array}$

* Listed in Table A6. 
We ruled out groups

for which we had too few (less than 20) observations in the union or nonunion sector. Thus we utilized 22 industries, 31 states, and 27 occupational categories (Table AG).

The intra-group union-nonunion wage differentials $3_{i}$ amounted, on average, to 15-20\%. They ranged from 0 to over $40 \%$ and were most prominent (larger and more significant) in the occupational category, less so within states, and least within industries.

Table 10 which reports the results of step 2 , shows respectively the effects of union status $(U)$, and of wage differentials $(\beta)$ on differences in quit rates between unionized and non-unionized workers within the various groups of workers. Effects of wage differentials are not significant within industries ( at a level higher than 1-digit. for workers with the same measured characteristics, but they are significant within regions and occupations. Union status alone (the $U$ dumm) is sufficient to affect the intra-industry differences, but plays no role other than via wage differentials inside occupations. Both variables are significant within states. Note also that $U$ is significant in all three groups, when $\beta$ is dropped, and conversely. 
4. Fringe Beneitits and Hours of Work

If numbers employed $(N)$ and hours per worker $(H)$ are viewed as separate factors of production, cost minimizing employers will determine their demand for $N$ and $H$ at the point where the ratio of marginal factor costs is equal to the ratio of marginal productivities, that is to the solpe of the optimal production isoçuant.

Following Rosen (1968), the equilibrium marginal factor cost ratio is.: ${ }^{1}$

(1) $\frac{M C_{N}}{M C_{H}}=\frac{H}{N}+\frac{F(r+q)}{N W}$

where $F$ is the fixed cost of employment per worker, amortized per period by $r$, the interest cost of capital and by $q$, the worker quit probability which depreciates the capital sum creating a capital loss Fq per period.

To the extent that $F$ is positive an increase in the wage rate $W$ reduces the factor cost ratio shifting the relative demand away from hours toward numbers. ${ }^{2}$ In the minimum wage case it may be argued that $F$ is significant at most in terms of training expenses, but that minimum wages tend to reduce or eliminate such expenses, so that the predicted effects on hours may be observed only in the short run before the adjustment is completed, or it may be indeterminate.

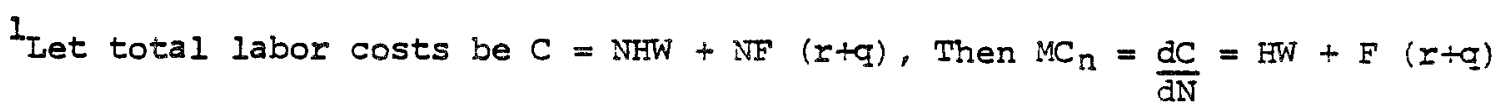
and $\mathrm{MC}_{\mathrm{H}}=\frac{\mathrm{dC}}{\mathrm{dH}}=\mathrm{NW}$

2 This analysis of substitution between $\mathrm{H}$ and $\mathrm{N}$ ignores scale effects. The qualitative conclusions, however, remain valid so long as the elasticity of demand for numbers (N) with respect to wages (including fringes) is less than unitary.
} 
In contrast to the minimum wage, union

pressure on wages extends to most components of the wage package.

Indeed, union push on components other than directly paid out wages appear to be even stronger. Union fringe benefits exceed non-union benefits not only in dollar value but also as a proportion of the wage package (about 30\%). A number of possible explanations have been conjectured, running from union democrasy which favors the older worker to union management of pension funds as an instrument of power. One economic argument relies on reduced turnover, which is a result of union wage push and of other gains. In the presence of incomplete vesting of pensions in the worker, longer tenure of union members means that the probability of ultimately receiving the pension is higher in union than in non-union jobs. Hence the incentive to push for larger pensions (Freeman, 1978). But why increase fxinge benefits by a larger percentage than the increase in the paid out wage? One reason is the higher marginal income tax rate, if the income elasticity of worker demand for fringes is otherwise unitary (Rice, 1966). But this may explain only a small part of the proportional increase (Donsimoni and Shakotko, 1979) ${ }^{2}$

The analysis of effects of wage push on hours may provide one rationale for union pressure on fringes: an increase in union wages $w$, with $F$ unchanged, would lower the ratio of marginal factor costs both by raising the denominator in the second right hand component of equation ( 1 ) and by reducing $q$ in the numerator. If hours are reduced, weekly earnings may not increase much even if wage rates rise significantly. To blunt the adverse effect on hours, more specifically, to prevent their reduction which would limit union gains in earnings, quasi-fixed costs, such as fringes, must be increased by a larger percentage than the paid out wage $(W)$, since quits $(q)$ decline when both $\mathrm{W}$ and $F$ are increased.

\footnotetext{
For the same reasons, more vesting is less costly to union than non-union employers. 2 They found that fringe benefitswere substantially larger for union workers whose total compensation (wages + fringes) was the same as the total compensation of non-union workers.
} 
In contrast to hypotheses which rely on non-wage aspects of unionism to explain the larger ratio of fxinge benefits to paid out wages in union employment, this analysis predicts a positive link between the percent union wage premium and the relative increase in fringe benefits (F). Moreover, the percent increase in $F$ is expected to exceed the percent increase in the wage, since the larger the latter, the bigger is the decrease in the quit rate. Thus unions which achieve the biggest gain in paid out wages would also want the largest proportion of their total compensation in fringe benefits. This proposition is tested on a sample of over 4,000 firms in 70 (2-digit) industries. Average paid out wages in union firms were $21 \%$ higher than in nonunion firms within the industry (a simple average of 70 wage ratios), while average fringe benefits were 60 s higher. The first regression (Table 11, Panel A). relates the ratios of fringes $\left(\frac{F u}{F n}\right)_{i}$, where $u$ is union, $n$ is nonunion, and $i$ is industry to ratios of money wages,standardizing for age of employees, size of firm, geographic region, and union coverage of the industry.

As predicted, the coefficient on the wage ratio in Table 11 is significantly larger than unity (1.62). This implies that a $10 \%$ increase in the union wage premium would create a $16 \%$ increase in the union-nonunion ratio of fringe benefits. This ratio was, on average, $32 \%$ in the unstandardized data.

A second test was performed, at the firm level on union firms alone. First a wage and fringe function was estimated on non-union firms in order to impute non-union levels of wages and fxinges to union firms. Thus the denominators of the wage ratio and the Iringe ratio. are imputed values which workers in union firms would receive if they were not unionized. This is a more stringent test because it relates fringes to wages in union firms only, and because errors in imputation bias the coefficients against the hypotheses (downward). The results (Table 11, Panel B) nevertheless, are once again as predicted, although the coefficient on the wage-ratio is, indeed, smaller than in panel A. 
Table 11

Fringe Benefits and Wages, Regressions on Industry (A) and Firm (B) Levels

(A) Industry Level--Panel A

\begin{tabular}{lcc} 
Variables & & T-Stat \\
\hline F-ERAT & - -Dep. & Variable -- \\
MWRAT & 1.6183 & 6.0 \\
TWRAT & -- & -- \\
SIZE_N & -0.0422 & -0.8 \\
SIZE_U & 0.0575 & 1.1 \\
SOUTH_N & 0.1750 & 0.9 \\
SOUTH_U & 0.0315 & 0.1 \\
URBAN_N & -0.0638 & -0.3 \\
URBAN_U & -0.0212 & -0.1 \\
YI_N & 0.9546 & 3.6 \\
YI_U & -0.6160 & -2.2 \\
Y2_N & 0.0161 & 0.1 \\
OLD & 0.0052 & 0.9 \\
COVER & 0.3413 & 1.8 \\
INTERCEPT & -0.9640 & -1.7 \\
& & \\
DFE & & 56 \\
F-RATIO & & 6.7 \\
R-SQUURE & & .61
\end{tabular}

(B) Firm Level--Panel B

\begin{tabular}{lcc} 
Variables & & T-Stat \\
\hline HFBRAT_U & -- Dep. & Variable -- \\
HTWRAT_U & 1.5167 & 41.3 \\
HMWRAT_U & -- & -- \\
COVER - & -0.4483 & -6.6 \\
C4 & 0.2748 & 3.2 \\
EDUCATION & -0.0503 & -2.0 \\
MAIE & 0.1217 & 1.7 \\
URBAN & 0.0485 & 2.2 \\
SOUTH & -0.0642 & -2.4 \\
SIZE & -0.0172 & -2.2 \\
YOUNG & 0.0001 & 0.1 \\
OID & -0.0018 & -0.7 \\
YI & 0.0150 & 0.6 \\
INTERCEPT & -0.4607 & -1.4 \\
& & \\
DFE & & \\
F-RATIO & & 2551 \\
R-SQUARE & & 146.6
\end{tabular}


Table 11

Fringe Benefit Regressions

Variables and Sources

Dependent Variable: F-BRAT, union/non-union fringe benefit ratio.

Independent Variables:

INDUSTRY -LEVEI REGRESSIONS: Panel (A)

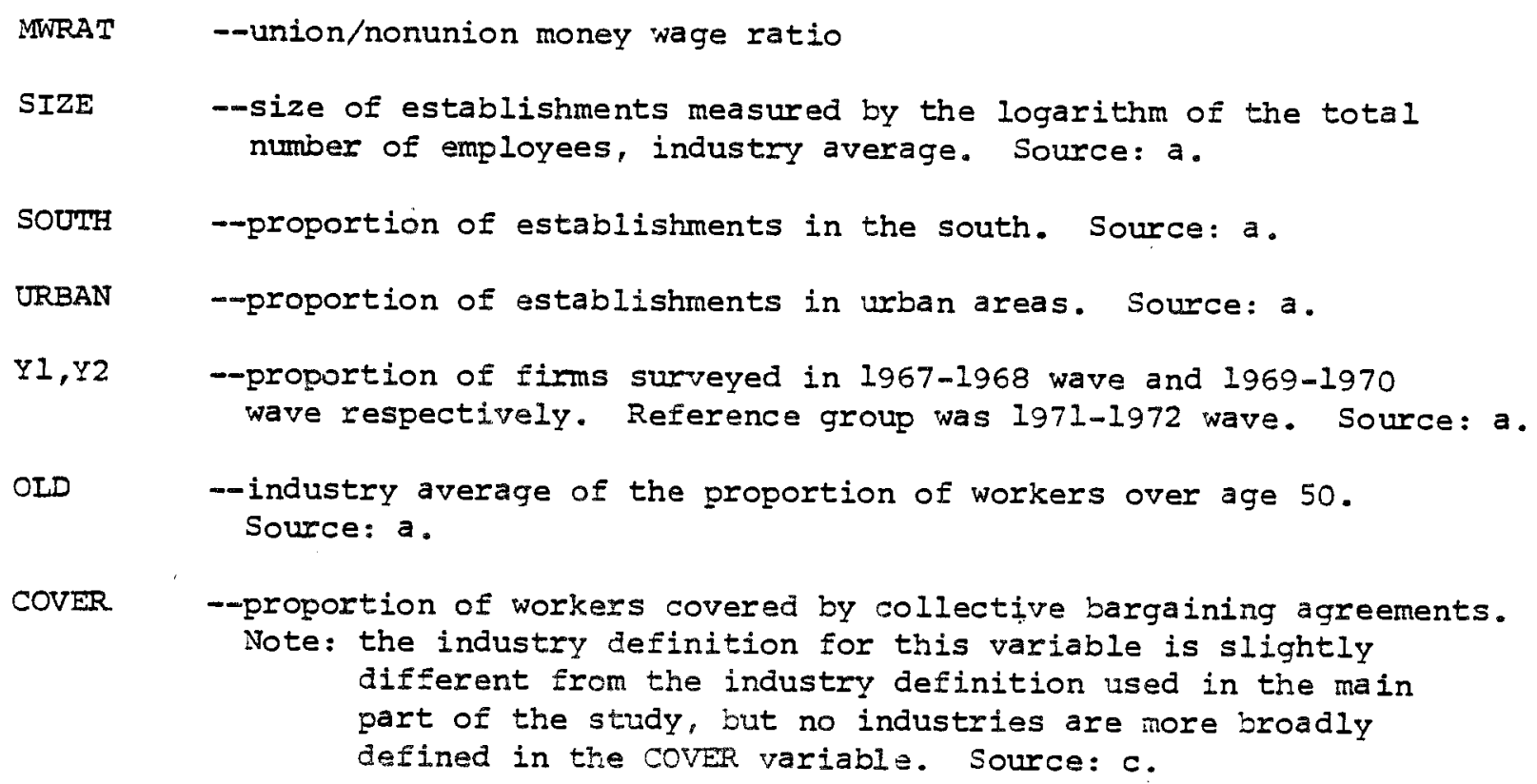

FIRM-LEVEL REGRESSIONS: Panel (B)

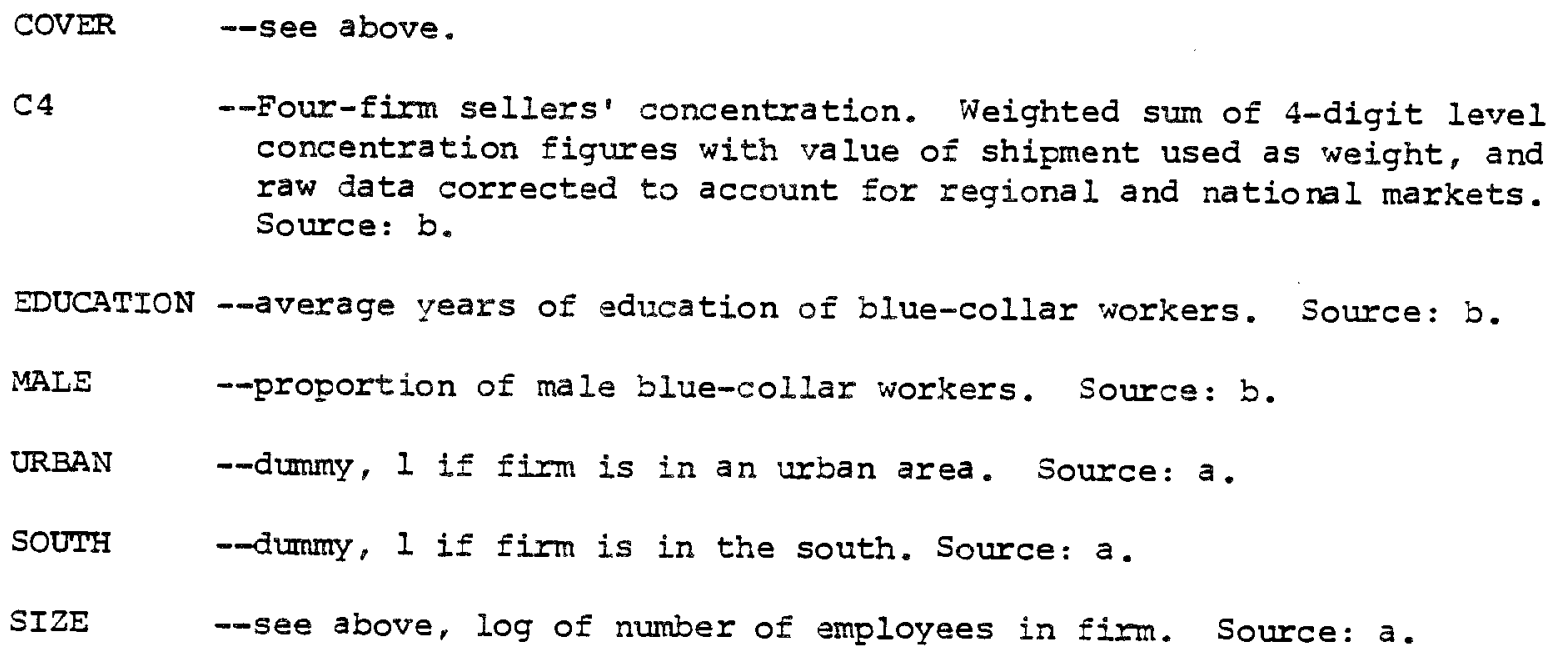


Firm-level regressions cont.

YOUNG
--percentage of firm employees under age 35. Source: $b$.
OLD
Y1,Y2
--percentage of firm employees over age 40. Source: b.

a Expenditures for Employee Compensation. Three surveys conducted by the Bureau of Labor Statistics in 1968, 1970, and 1972 have been pooled. They include 4,073 establishments, 2,580 unionized and 1,493 nonunionized.

b May Current Population Survey. Three surveys conduced 1973, 1974, and 1975 have been pooled. They include 50,000 households with 49 percent of union members.

c Richard Freeman and James Medofi. "New Estimates of the Industrial Unionism in the U.S." Industrial and Labor Relations Review, January 1979, 143-174. 
In the data analyzed in Table 11 the value of union fringes is 80 higher than of nonunion fringes, while wages are $30 \%$ higher. Ascuming trat the net union effect is a half of this figure (i.e. 15z), and that quit rates are half as large in the nonunion sector (as observed in Table 7), we can calculate the required ratio of Eixed costs $\frac{F_{u}}{E_{n}}$ which would remove employer incentives to cut hours schedules of union workers. Given $\mathbb{N}$ (numbers employed), the condition is, by eg. (1):

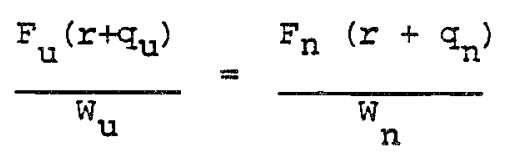

Assuming $r=10 \%$, and $q_{n}=10 \%, \frac{F_{u}}{F_{n}}=\frac{w_{n}\left(r+q_{n}\right)}{w_{n}\left(r+q_{U}\right)}=1.15 \times \frac{4}{3}=1.53$.

The actual ratio of fringe benefits is larger (1.80), presumably because fringes represent only a part, although a major one, of fixad labor costs.

An important consequence of higher fixed costs (in hiring and in fringes) imposed on union employers is greater stability of employment--reduced fluctuations in $\mathrm{N}$, when labor demand fluctuates (see Rosen, 1968). As a result, the major means of adjustment to fulctuating demand in union employment are the use of overtime when labor is short and the use of temporary layoffs (recall unemployment) in slack times. Temporary layoff is favored by union workers, as it implies lesser income loss than corresponding reductions in weekly hours, because of unemployment compensation and other unemployment benefits (see b). For their part, employers can expect less attrition, since temporarily laid off union workers are less likely to look for other jobs than comparable non-union workers. The evidence that average weekly hours are not less in the union than non-union sector, that overtime is more prominent and that temporary layoffs are more frequent and a larger porportion of total layoffs in the union sector is available ${ }^{1}$, and consistent with our hypothesis. In this light union pressure on fringe benefits is not merely (or at all) a tradeoff for higher wages, but a policy which increases both earnings and job security of union workers.

In MID, straight-time in weekly hours are about $4^{\frac{s}{2}}$ shorter in union jobs, but total hours are no less in union than in nonunion jobs. See also Blau ana kahn (1981), and Raisian (1981). 
5. Union Wage Profiles and Job Training

The cross-section union-nonunion differentials in wages diminish with age. They are reduced from over $22 \%$ to about $15 \%$ between ages less than and more than 30 for union stayers $\left(U_{11}\right)$ in MID (Table 5), and reduced further to a little over zero for those over 48 in NLS (Table 4). The implication is that the typical union age (experience) wage profile, although higher in level is flatter than the typical non-union profile. This difference has been found in other studies and has been ascribed to union policy of compressing wage differentials across firms and workers, who may differ in sex, education, race, and age.

The policy of wage compression has been attributed to union pursuit of equity, to administrative convenience in collective bargaining, and to union efforts to reduce competition from lower wage firms. However, a more direct explanation of flatter wage profiles involves union emphasis on wage progression by seniority rules: Within the firm, the wage structure and other rales of collective bargaining agreements are specified in terms of seniority, or job tenure. Although wages grow as tenure lengthens in non-union jobs as well as in union jobs (Table 12), the explicit seniority rules in union firms are a great deal more rigid: Seniority is the necessary condition for promotion in most union firms. If the higher job level requires additional training, union clauses often provide that senior employees are to be trained in order to fill the higher level vacancies. 1 such provisions limit the supply of trained workers Irom the outside. At the same time they severely reduce the benefits from transferable training. Consecuently, incentives for general (transferable) training are reduced for union workers, both because such training is not adequately rewarded within the union firm, and because union workers are less likely to move in the first place.

\footnotetext{
Isee BIS BuIletin, "Union Status and Benefits of Retirees", July 1973.
} 
Table 12

\section{Union and Non-union Wage Functions}

\section{MID, Pooled, 1968-1978}

(A) Wage Level (InW)

\begin{tabular}{|c|c|c|c|}
\hline & Union & Nonun: & ion \\
\hline$E d$ & $5.0 \quad(22.4)$ & $9.6(46.4)$ & \\
\hline$z$ & $1.7(10.6)$ & $3.7(21.2)$ & \\
\hline$x^{2}$ & $-0.2(7.4)$ & $-0.6(17.9)$ & \\
\hline $\mathbf{T}$ & $2.4 \quad(12.5)$ & $2.1(9.3)$ & $1.6(6.5)$ \\
\hline$T^{2}$ & $-.06(8.1)$ & $-.03(3.2)$ & $-.02(2.2)$ \\
\hline Mar & $.4(.2)$ & $13.1(7.1)$ & \\
\hline Hith & $-7.3(4.4)$ & $-12.7(6.1)$ & \\
\hline LocUn & $1.2(6.1)$ & $2.7(11.1)$ & \\
\hline M & $-.8(.9)$ & & $-5.5(5.1)$ \\
\hline
\end{tabular}

(B) Wage Growth ( InW)

Union 1 Nonunion

$.1(.5) \quad-.2$ (1.I)

$2.0(.5): 6.5(1.9)$

$-.04(1.7) \quad-.06(2.3)$

$1.0(1.5) \quad 1.0(2.2)$

$-.03(.9) \quad-.02(.3)$

$-.3(.2) \quad-.4(.3)$

$-4.2(2.5) \quad 2.6(1.3)$

$.1(.7) \quad .1(.7)$

$.2(.3),-1.3(1.6)$ 
This helps to explain the declining with age proportion of job movers who join union firms (Table 1 ), and the smaller coefficient of experience ${ }^{1}$ at fixed levels, in the wage function of union compared to non-union workers (Table 12).

Whatever training exists in union firms, and certainly some initial (apprentice) training exists in crafts, and is provided for the purposes of filling more skilled vacancies from within, almost by definition, all of it is specific to the firm. If wage growth with tenure at fixed levels of experience reflects the growth of specific capital, tenure-wage profiles in union firms need not be flatter and may even be steeper than in non-union firms.

This is, indeed, found in Table 12, where the coefficient on tenure in the union wage equation is no smaller than in the non-union equation. Table 12 is restricted to MID data because estimates of experience and tenure coefficients in NLS are sensitive to truncation by age. The non-union tenure coefficient in the wage level equation (left-hand panel) is smaller in col. (3), where an attempt was made to adjust the estimate for heterogenity bias ${ }^{2}$ by introducing the (prior) mobility rate variable. This variable (M) has a negative and significant effect in the non-union equation, where it also reduces the tenure coefficient, but has no effect in the union equation. The right-hand panel of the Table shows separate wage growth equations for union and nonunion workers. The comparative results are similar to the results in wage levels, but all coefficients are smaller and less significant.

\footnotetext{
IAnd of education, if job training is complementary. 2 For an introduction of this approach, see Mincer and Jovanovic (1978).
} 
The experience coefficient is much smaller in the union equation. Thus the flatness of gross union wage profiles (by age, or experience) when tenure is ignored, or by tenure when experience (or age) is ignored is due solely to lesser worker investments in general training.

The flatter gross union profile also suggests that the total volume of training is smaller in union firms. In principle, this need not be the case, since the wage profile measures returns to workers, but not returns on costs borne by employers. The reluctance of union workers to guit should provide incentives for union employers to invest in specific training of their workers, since the risk of a capital loss by worker quit is smaller. Union workers have a corresponding insurance against capital losses only to the extent that seniority rules reduce layoffs.This is true at higher levels of seniority at the expense of low-tenured workers. Thus, in contrast to the usual (competitive) analysis (Becker, 1975) where worker turnover - both quits and layofis - are a result of investments in specific human capital shared by workers and employers, such investments are the result, rather than cause, of turnover patterns induced by union pressure.

Because of lower guit, we might expect employer investments in specific training of union workers to exceed the corresponding investments of non-union employers. But the fact that permanent layoff rates of union workers are no smaller than in the non-union sector raises doubts about such expectations. However, higher rates of union layoffs concentrated at low tenure levels may both reflect additional screening of new hires and may be a substitute form of adjustment for reduced quit. I If the volume of specific training is not clearly larger in union firms, total training, including the general component, is likely to be smaller. This is apparently confirmed by the more direct evidence on reported training, to which we proceed:

I Blau and Kahn find that unionism increases permanent layof ss among the young, not among the old NLS. Our own research (not oresented here) shows that while quits and layoffs decline with tenure at about the same rate for non-union workers, layoffs decline more steeply than quits for union workers. 
In the NLS, training was reported in response to questions: Do you receive or use additional training (other than school training) on your job? In MID, different questions were used in different surveys; the most appropriate for our purposes is the question asked in 1976-1978: "Are you learning skills on the current job which could lead to a better job or to promotion?"

In a recent paper (Mincer and Leighton, 1981) these questions were used to explore the effects of minimum wage laws on training on the job. Training so reported was used as a dependent variable ${ }^{l}$ in the NLS and MID equations (the same set of independent variables was used as in the wage equations). A union dummy included in those equations was significantly negative in all periods in the MID and in the older NLS sample.

In the current study, we further classified the union status variable as joiners $\left(U_{01}\right)$, leavers $\left(U_{10}\right)$, and stayers $\left(U_{11}\right)$, and explored the incidence of training before and after the change of union status.

In the NLS samples (Table 13, (A) ) the old union stayers and union joiners show significantly less training than non-union stayers. The signs on coefficients of the young union joiners are negative, not significant before joining and almost significant after. Old union leavers show positive, but not significant coefficients.

The MID results (Table $13(B)$ ) similarly show significantly less training among union stayers $\left(U_{11}\right)$. They also show that less training is required on union jobs, though not as a precondition for hiring (coefficient $U_{01}$ is not significant in year 1, Panel C). The coefficients of union joiners are negative and not significant before but significant after joining the union (year 1 and year 2 regressions). Inferentially, they received more training than union stayers before the start of the union job. Conversely, union leavers appear to receive more training than before on the non-union job to which they moved.

IAs an independent variable, the training dummies are positve and significant in both wage level and wage growth equations (not reported here). 
(A) Union Effects on Training, NLS 1969-1971

Training in 1969 Job

\begin{tabular}{llll} 
& Young & \multicolumn{1}{l}{ Old } \\
$U_{01}$ & $-3.1(.7)$ & $-6.5(1.8)$ \\
$U_{10}$ & $-1.3(.3)$ & $4.6(1.1)$ \\
$U_{11}$ & $-.4(.1)$ & $-5.1(2.9)$
\end{tabular}

(B) Union Effects on Training, MID 1976-1978

$$
\text { (Ages } \leq 45)
$$

Year 1 (1976)

U

$U_{10} \quad-14.4 \quad(2.4)$

$U_{11}-15.0 \quad(5.3)$

Year 1 (1976)

$U_{01}-3.9(.6)$

$0_{10} \quad-7.5(1.1)$

$u_{11}-6.7(2.1)$
Training in 1971 Job

Young

$\underline{\text { old }}$

$-5.5(1.3)$

$-4.9(1.4)$

$-.3(.1)$

$2.7(.6)$

$-3.6(1.3)$

$-7.4(4.1)$

(C) Is Non-School Training Required for Current Job?

$$
\text { (MID, Eaucation } \leqslant 12 \text { ) }
$$

Year 2 (1978)

$-11.5(3.0)$

$-3.8(.9)$

$-12.9(5.8)$

\section{Year 2 (1878)}

$-6.8(1.7)$

$3.6(.8)$

$-9.7(4.2)$ 
The findings on workers who changed union status are not very secure, but they suggest that selectivity in hiring may involve prior training (in addition to some cencentration of it at the outset of some of the union jobs, such as in crafts). This may explain the results for the very young NLS workers where union effects on training were not significant.

The finding that union workers receive less training on the job than nonunion workers is also confinmed in the Michigan Time Study, as reported by Duncan and Stafford (1980). They report that while non-union worker spend, on average 6.1 hours per week on job training, comparable union workers spend 4.2 weekly hours on such training.

Summary

Amoung a number of features that distinquish unionized from non-unionized labor markets, at least four have been repeatedly observed in empirical studies: (1) Higher wages, (2) Larger fringes, more than in proportion to wages, (3) Lesser turnover, reflecting lesser quit, though not less layoffs, and (4) Flatter agewage profiles. Although the labor monopoly hypothesis has been used (and disputed) as an explanation of higher union wages, it does not receive much, if any, attention in andyses of the other features.

This study explores the existence of a net union premium and of the extent of rationing by quality of the resulting excess supply. The net union premium was estimated in Section 1 by relating changes in wages to changes in union status of the same worker in longitudinal panels (NLS and KID). In section 2, two crosssection wage level regressions, a "prospective" and "retrospective" permit more direct observation of selectivity in hiring. Over a half of the cross-section differential of over $20 \%$ for the "same" (standardized) worker is a net union rent and much of the rest reflects a quality adjustment in hiring, as measured by wages. This conclusion was less reliable for older workers. 
The next step (Section 3)was to ascextain whether the net union wage premium is responsible, together with other advantages secured by the union such as fringes and seniority rules, for the lesser turnover, especially guit of union workers. The answer is positive: the reduction in quit depends on the size of the net wage premium in an individual analysis, and is also positively related to the gross, cross-section wage differentials within groups of workers, olassified by location and occupation, though not by industry. Frtnges and senjority rulos, or other union advantages did not explicitly enter this analysis hit they are likely to be embodied in the union menisuship variable.

In Section 4 , it is hypothesiaed that the inoosition of laxyer fixod lator costs (such as fringes) helps to deter employers fron preforotig rabotions in hours to reductions in men, and it helrs to stabilize employment in the rawe of fluctuating demand,by a mora frocuent use of overtime and of temporay layof in in the union sector. This hypothesis iinks tha size of fringe benefits th the inion wage gain. An analysis of firms in m inchstries confinus this link.

Section 5 explored the consequences of union prossure on the tenure profile of wages by the rather rigid linking of we levels to seniority in the job. Tho consequently reduced incentives for workr investment in general (wansferablo) training, even jf no such reduction nows to aply wo specifiu tre inim, is consistent with observed flatter experion (or age) profile of wages of vinu workms. In sum, total training is likely to be less Erequent in union fim; ani this is confirmed by direct responses in survey roports. 
Abowd, John and Henry Farber."Job Queues and the Union Status of Workers," Unpublished, 1981.

Ashenfelter, Orley and George E. Johnson. "Unionism, Relative Wages, and Labor Quality in U.S. Manufacturing Industries," International Economic Review, XIII, (October, 1972), 488-507.

Becker, Gary. Human Capita 1, Columbia University Press, 1975.

Blau, Francine D. and Lawrence M. Kahn. "The Exit-Voice Tradeoff in the Labor Market: Some Additional Evidence." (Mimeograph, 1981).

Bloch, Farrell E. and Mark S. Kuskin. "Wage Determination in the Union and NonUnion Sectors," Industrial and Labor Relations Review, XXXXI (January, 1978), $183-192$

Brown, Charles. "Equalizing Differences in the Labor Market," Quarterly Journal of Economics, XCIV (February, 1980), 113-134. and James Medoff. "Trade Unions in the Production Process," Journal of Political Economy, LxxXVI (June, 1978), 355-378.

Chamberlain, Gary. "On the Use of Panel Data," Unpublished, 1978.

Clark, Kim B. "The Impact of Unionization on Productivity: A Case Study," Industrial and Labor Relations Review, XXXIII (July, 1980a), 451-469. - "Unionization and Productivity: Micro-Econometric Evidence," Quarterly Journal of Economics, XCV (December 1980b), 613-639.

Donsimoni, Marie-Paule and Robert $A$. Shakotko. "Unionism and the Structure of Total Compensation," (Mimeograph, 1979).

Duncan, Gregg, in Five Thousand American Families, (vol. VIII, 1979). and Frank P. Stafford. "Do Union Members Receive Compensating Wage Differentials?" American Economic Review, IXX (June, 1980), 355-371.

Farber, Henry S. "Unionism, Labor Turnover, and Wages of Young Men," (Mimeograph, 1979).

Freeman, Richard B. "The Exit-Voice Tradeoff in the Labor Market, Unionism, Job Tenure, Quits, and Separations," Quarterly Journal of Economics, XCIV (June 1980b), 643-673. - "Unionism and the Dispersion of wages," Industrial and Labor Relations Review, XXXIV (October, 1980c), 3-23. - "The Effect of Trade Unionism on Fringe Benefits," Industrial and Labor Relations Review, XxxIV (July, 1981).

Johnson, George E. "Economic Analysis of Trade Unionism," American Economic Review, LXV (May, 1975), 23-28.

and Kenneth Younams. "Union Relative Nage Effects by Age and Education," Industrial and Labor Relations Review, (January, 1971).

Jovanovic. Boyan and Jacob Mincer. "Labor Mobility and Wages," Studies in Labor Markets, (NBER Conference, 1978), S. Rosen, ed., in press.

Kalachek, Edward and Frederick Raines. "Trade Unions and Hiring Standards," Journal of Labor Research, (Spring, 1980).

Kenny, Lawrence $w$. "Male Wage Rates and Marital Status," Unpublished, 1978.

Leighton, Linda and Jacob Mincer. "The Effects of Minimum Wages on Human Capital Formation," The Economics of Legal Minimum wages, S. Rottenberg, ed., (AEA Conference, 1981).

Lewis, \#. Gregg. Unionism and Relative Wages in the United States. Chicago: University of Chicago Press, 1963.

- "Competitive and Monopoly Unionism," Public Stake in Union Power, P. Bradley, ed., (University of Virginia press, 1959). 
Medoff, James I. "Layoffs and Alternatives under Trade Unionism in U.S. Manufacturing," American Economic Review, LXIX (June, 1979), 380-395.

Mellow, Wesley. "Unionism and Wages: A Longitudinal Analysis," Review of Economics and Statistics, LXIII (February, 1981a), 43-52.

Mincer, Jacob. "The Economics of Wage Floors," (Paper delivered at annual AEA Meetings, September, 1980).

Mitchell, Daniel J.D."Some Empirical Observations of Relevance to the Analysis of Union Wage Determination," Journal of Labor Research, (Fal1, 1980).

?arsley, C.J. "Labor Unions and Wages: A Survey," Journal of Economic Iiterature, (March, 1980).

Pencavel, John. An Analysis of the Quit Rate in American Manufacturing Industry. Princeton, New Jersey: Industrial Relations Section, 1980.

Raisian, John. "Contracts, Tenure, ana Cyclical Variability in Wages and Hours," (BLS Mimeograph, April, 1981).

Rice, Robert G. "Skill, Earnings, and the Growth of Wage Supplements," American Economic Review, IVI (May, 1966), 583-593.

Rosen, Sherwin. "Short-run Employment Variation on Class I Railroads in the U.S.," Econometrica, (July, 1968). 


\section{Appendix Tables}

Table Al

NLS wage Equations

(a) Wage Growth

$\Delta$ lnw (1969 to 1971)

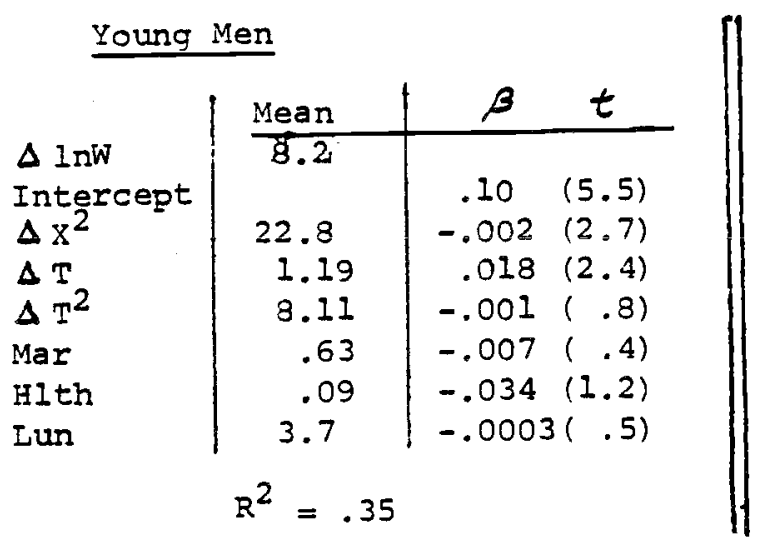

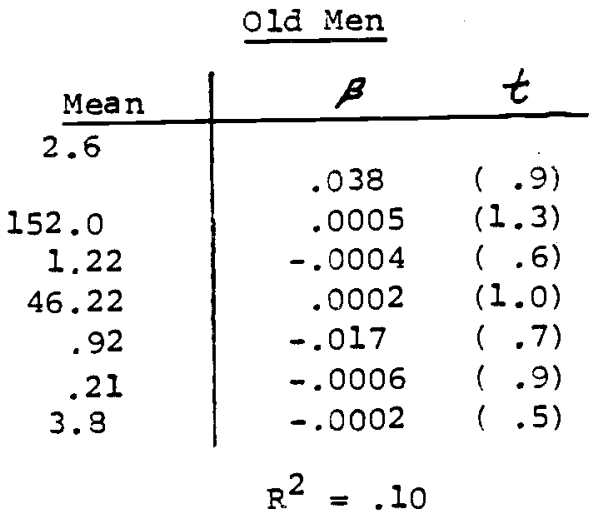

(b) Wage Level (69)

\begin{tabular}{l|c|cl||}
\multicolumn{2}{c|}{ Young Men } \\
lnw & Mean & $\beta$ & $t$ \\
\hline Intercept & 1.12 & -.19 & $(2.4)$ \\
Educ & 12.2 & .078 & $(15.6)$ \\
$\mathrm{X}$ & 6.7 & .045 & $(4.5)$ \\
$\mathrm{X}^{2}$ & 57.8 & -.001 & $(1.3)$ \\
$\mathrm{T}$ & 1.65 & .024 & $(2.2)$ \\
$\mathrm{T}^{2}$ & 7.12 & -.002 & $(1.5)$ \\
Mar & .63 & .096 & $(4.5)$ \\
HIth & .09 & -.024 & $(.8)$ \\
Lun & 3.7 & -.002 & $(.4)$ \\
& \multicolumn{3}{|c}{} \\
& $\mathrm{R}^{2}=.36$
\end{tabular}

\begin{tabular}{c|cc} 
& \multicolumn{1}{|c}{ Old Men } \\
\cline { 2 - 3 } Mean & $\beta$ & $t$ \\
1.34 & 1.21 & $(2.5)$ \\
10.3 & .053 & $(11.5)$ \\
39.0 & .033 & $(1.4)$ \\
1551.4 & -.0003 & $(1.0)$ \\
14.8 & .003 & $(1.1)$ \\
342.2 & -.0001 & $(1.4)$ \\
.92 & .238 & $(5.9)$ \\
.21 & .043 & $(1.5)$ \\
3.8 & .001 & $(1.5)$ \\
& &
\end{tabular}


Table A2

MID Wage Equations

1968-1978, annual, pooled

(a) Wage Growth

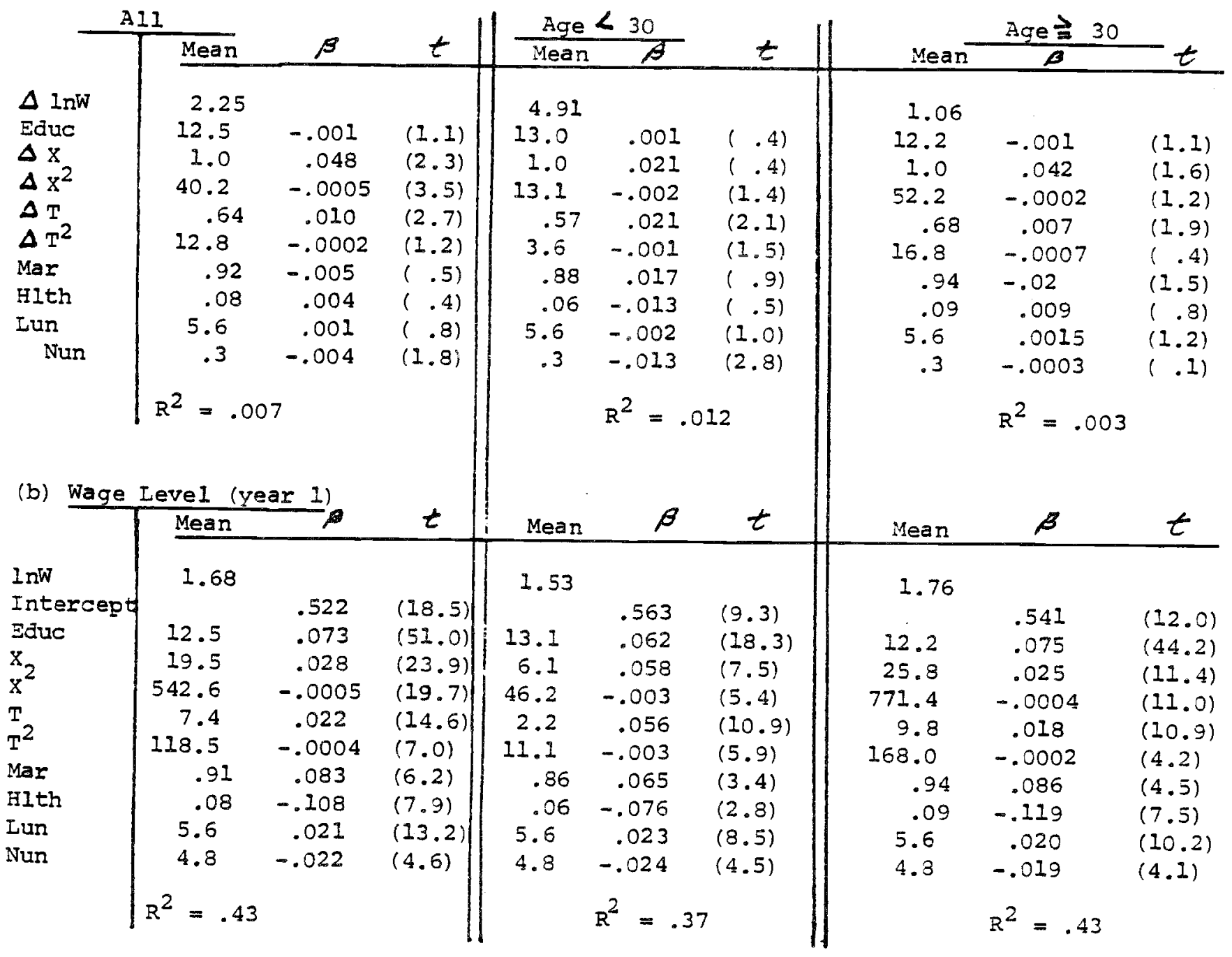


(a) Wage Gains ( $(z)$ of Movers, by Union Status, and by Quit (Q) and Layoff (L) NLS, 1967-1969

Young Men

\begin{tabular}{|c|c|c|c|c|c|c|c|c|}
\hline \multirow[b]{2}{*}{$\mathrm{U}_{012}$} & \multicolumn{2}{|c|}{ (UTM) } & \multicolumn{2}{|c|}{ (CB) } & \multicolumn{2}{|c|}{ (UM) } & \multicolumn{2}{|c|}{ (CB) } \\
\hline & $\overline{17.3}$ & $(2.8)$ & 13.1 & $(2.6)$ & $\overline{5.5}$ & $(.4)$ & 16.7 & $(1.1)$ \\
\hline U & 15.1 & $(2.5)$ & 10.1 & $(1.6)$ & -8.1 & $(.4)$ & 4.2 & $(.3)$ \\
\hline $\mathrm{U}_{10^{2}}^{1}$ & -24.4 & $(4.3)$ & -23.6 & $(4.4)$ & -9.4 & $(.6)$ & -17.6 & $(1.0)$ \\
\hline$U_{10}^{L}$ & -31.4 & $(5.0)$ & -37.0 & $(6.7)$ & -16.7 & $(.6)$ & -27.9 & $(1.8)$ \\
\hline Q & 10.6 & $(1.6)$ & 11.4 & $(2.0)$ & 10.6 & $(.5)$ & 10.2 & $(.5)$ \\
\hline$U_{I I}^{I I}$ & 3.4 & $(.6)$ & 3.0 & $(.6)$ & $3=8$ & $(.6)$ & 3.4 & $(.5)$ \\
\hline $\mathrm{U}_{00}^{+1}$ & 5.1 & $(1.8)$ & 6.0 & $(2.0)$ & -1.9 & $(.4)$ & -3.9 & $(.7)$ \\
\hline $\mathrm{U}_{00^{\mathrm{I}}}$ & -4.8 & $(1.4)$ & 2.3 & $(.6)$ & -12.0 & $(1.7)$ & -10.9 & $(1.5)$ \\
\hline
\end{tabular}

(b) Wage Gain of Movers, by Union Status and by Industry * Change $(B=$ moved between industries; $W=$ moved within industries $)$

\begin{tabular}{|c|c|c|c|c|c|c|c|c|}
\hline $7^{B}$ & 18.8 & $(4.0)$ & 13.4 & $(2.9)$ & 2.4 & $(.1)$ & 8.1 & $(.7)$ \\
\hline $17^{6}$ & 4.3 & $(1.5)$ & 5.6 & $(1.7)$ & 2.3 & $(0)$ & 7.7 & $(.5)$ \\
\hline $\mathrm{U}_{10^{\mathrm{B}}}^{\mathrm{B}}$ & -33.5 & $(6.4)$ & -35.0 & $(7.7)$ & -9.1 & $(1,4)$ & -35.7 & $(2.4)$ \\
\hline U & -12.9 & $(1.7)$ & -13.0 & $(1.7)$ & -17.9 & $(.9)$ & -10.0 & $(.6)$ \\
\hline${ }^{B}$ & 5.7 & $(.8)$ & 6.9 & $(1.2)$ & 3.7 & $(.3)$ & 3.4 & $(.3)$ \\
\hline$\frac{1}{11} W$ & 6.1 & $(1.2)$ & 6.0 & $(1.1)$ & 3.2 & $(.4)$ & 2.9 & $(.4)$ \\
\hline $00^{B}$ & -.8 & $(.3)$ & 3.2 & $(1.3)$ & -28.9 & $(4.8)$ & -30.7 & $(4.8)$ \\
\hline $\mathrm{J}$ & 7.2 & $(2.0)$ & 8.0 & $(2.2)$ & 15.1 & $(2.6)$ & 13.9 & $(2.4)$ \\
\hline
\end{tabular}


Table A4

Wage Gains in MID

(a) Movers, by Union Status and by Quit and Layoff

MID, pooled

\begin{tabular}{|c|c|c|c|c|c|c|}
\hline \multicolumn{3}{|c|}{ AlI } & \multicolumn{2}{|c|}{ Age $<30$} & \multicolumn{2}{|c|}{ Age $>30$} \\
\hline$U_{0}$ & 17.2 & $(4,4)$ & 19.8 & $(3.6)$ & 11.8 & $(1.8)$ \\
\hline I & -2.8 & $(.6)$ & -1.9 & $(.3)$ & -3.3 & $(.5)$ \\
\hline 2 & & $(.1)$ & -9.9 & $(1.6)$ & 12.1 & $(3.0)$ \\
\hline & -2.8 & $(.4)$ & -7.4 & $(1.0)$ & 5.2 & $(1.0)$ \\
\hline & 10.6 & $(2.7)$ & 10.9 & $(1.8)$ & 11.6 & $(2.0)$ \\
\hline$U_{I I}^{\frac{1}{1}} \bar{L}$ & 5.6 & $(1.6)$ & -2.3 & $(.3)$ & 10.7 & $(2.6)$ \\
\hline$U_{0 O^{2}}$ & 9.0 & $(5.6)$ & 12.4 & $(4.6)$ & 4.6 & $(2.0)$ \\
\hline$U_{00}{ }^{L}$ & .7 & $(.3)$ & 2.4 & $(.7)$ & -.8 & $(.3)$ \\
\hline
\end{tabular}

(b) Movers, by Union Status, and Industry Change

\begin{tabular}{|c|c|c|c|c|c|c|}
\hline $\mathrm{U}_{01}{ }^{B}$ & 10.1 & $(2.1)$ & 11.2 & $(3.4)$ & 4.2 & $(.6)$ \\
\hline$U_{0 I}{ }^{W}$ & -.4 & $(.7)$ & 5.6 & $(.7)$ & -6.9 & $(2.0)$ \\
\hline & -7.2 & $(1.7)$ & -10.1 & $(1.5)$ & -5.6 & $(.9)$ \\
\hline on & -.2 & $(.4)$ & -.6 & $(.1)$ & 4.5 & $(.9)$ \\
\hline$B$ & 12.1 & $(2.7)$ & 25.2 & $(2.0)$. & 12.4 & $(2.1)$ \\
\hline & 3.0 & $(.8)$ & 1.3 & $(.2)$ & 5.5 & (1.1) \\
\hline & 6.9 & (3.8) & 8.7 & $(3.0)$ & 7.3 & $(2.8)$ \\
\hline$W_{W}$ & 3.2 & $(1.5)$ & 8.5 & $(2.4)$ & -1.4 & $(.4)$ \\
\hline
\end{tabular}


$\underline{\text { Table A5 }}$

(a) Mobility Rate Regression, MID, Cross-section pooled

\begin{tabular}{|c|c|c|c|c|}
\hline \multicolumn{3}{|c|}{$\underline{\operatorname{lnM}}$} & \multicolumn{2}{|l|}{$\underline{M}$} \\
\hline Educ | & -.050 & $(7.3)$ & -.015 & $(4.8)$ \\
\hline & -.048 & $(7.0)$ & -.031 & $(9.9)$ \\
\hline$x^{2}$ & .0004 & $(3.0)$ & .0002 & $(1.2)$ \\
\hline Mar & -.092 & $(12.8)$ & -.050 & (15.1) \\
\hline Hith & .001 & $(.3)$ & -.001 & $(.2)$ \\
\hline Nun & -.454 & $(9.2)$ & -.421 & (18.5) \\
\hline Union & -.093 & $(2.5)$ & -.042 & $(2.6)$ \\
\hline & $=.62$ & & $\mathrm{R}^{2}$ & .55 \\
\hline
\end{tabular}

(b) Quit Rate Regressions, MID, Cross-section

\begin{tabular}{|c|c|c|c|c|c|c|}
\hline \multicolumn{4}{|c|}{ Union } & \multicolumn{3}{|c|}{ Non-union } \\
\hline 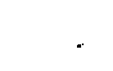 & Mean & $\beta$ & $t$ & Mean & $B$ & $t$ \\
\hline 2 & .039 & & & .083 & & \\
\hline \multicolumn{2}{|c|}{ Intercept } & .157 & $(6.2)$ & & .275 & $(13.1)$ \\
\hline Educ & 11.4 & -.0016 & $(1.1)$ & 13.0 & -.0053 & $(4.5)$ \\
\hline$x_{2}$ & 22.4 & -.0040 & $(3.5)$ & 18.6 & -.0068 & $(6.8)$ \\
\hline$x^{2}$ & 666.2 & .00004 & $(2.0)$ & 500.0 & .00007 & $(3.6)$ \\
\hline $\mathrm{T}_{2}$ & 9.0 & -.0036 & $(2.5)$ & 6.6 & -.0080 & $(5.4)$ \\
\hline $\mathrm{T}^{2}$ & 151.8 & .0001 & $(2.2)$ & 99.4 & .00027 & $(5.1)$ \\
\hline Mar & .94 & -.027 & $(2.0)$ & .91 & -.012 & ( 1.1$)$ \\
\hline HIth & .09 & .018 & $(1.6)$ & .08 & .023 & $(1.9)$ \\
\hline $\ln M^{*}$ & -.0048 & .010 & $(1.7)$ & .0038 & .043 & $(6.8)$ \\
\hline \multicolumn{3}{|c|}{$\mathrm{R}^{2}=.03$} & & \multicolumn{2}{|c|}{$\mathrm{R}^{2}=.06$} & \\
\hline
\end{tabular}

*Prior mobility rate. 
Table A6

Estimates of Group Wage Differentials, MID, Pooled

I. A category was excluded if the number of union observations in it was less than 20 in the full sample.

The coefflicients reported below represent the percent union differential

for each category. The dependent variable is log defalted average hourly earnings. No intercept was used so that levels rather than contrasts could be read for the group dummies (not reported here).

(1) The first set of dummies refers to detailed industries:

\begin{tabular}{|c|c|c|c|}
\hline VARIABLE & $\begin{array}{l}\text { PARAMETER } \\
\text { ESTIMATE }\end{array}$ & T RATIO & \\
\hline IUOl & 0.192876 & 2.6447 & mining and extraction \\
\hline IUO2 & 0.030812 & 0,8054 & metal industries (manuf.) \\
\hline IUO3 & -0.027250 & -0.9070 & machinery, incl. electric (manuf.) \\
\hline IU04 & 0.098406 & 3.2413 & motor vehicles, other transportation equipment (manuf.) \\
\hline IUO5 & 0.120014 & 3.4501 & other durables (manuff.) \\
\hline IU06 & 0.117478 & 2.5718 & food and kindred products (manuf.) \\
\hline IUO7 & 0.281642 & 4.1110 & textiles, apparel, shoes (manuf.) \\
\hline IU08 & 0.028735 & 0.3106 & paper and allied products (manuf.) \\
\hline IU09 & -0.110420 & -2.5741 & chemical, allied products (manuf.) \\
\hline IU10 & 0.349179 & 12.4312 & construction \\
\hline IUII & 0.130612 & 3.9211 & transportation \\
\hline IU12 & 0.084606 & 1.4231 & communication \\
\hline IU13 & 0.168903 & 3.5534 & other public utilities \\
\hline IU14 & 0.273232 & 7.1365 & retail trade \\
\hline IU15 & -0.043016 & -0.8688 & wholesale trade \\
\hline IU16 & 0.110787 & 1.2200 & repair service \\
\hline IU1 7 & 0.142907 & 1.4794 & personal services \\
\hline IU18 & 0.184840 & 2.7868 & printing, publis hing, allied services \\
\hline IU19 & -0.073909 & -0.9493 & medical and dental and health services, public or private \\
\hline IU20 & 0.136501 & 3.9973 & educational services, public or private \\
\hline IU2 1 & 0.219599 & 2.7867 & $\begin{array}{l}\text { professional and related services other than medical } \\
\text { or dental }\end{array}$ \\
\hline \multirow[t]{4}{*}{ IU22 } & 0.138157 & 4.3291 & $\begin{array}{l}\text { government, other than medical or educational services; } \\
\text { NA whether other }\end{array}$ \\
\hline & F RATIO & 4701.32 & \\
\hline & DFE & 8463 & \\
\hline & R-SQUARE & 0.9682 & \\
\hline
\end{tabular}


(2) The second set of dumies refers to states of the continental U.S.A. These states vere dropped:

Alabama

Colorado

Delaware

District of Columbia

I Caho

Kansas

iouisiana

Montana

Ilebraska

Neva da
New Haupshice

Wew Merico

North Dakota

Rhode Island

South Carolina

Vermont

vest Virginia

wyoming

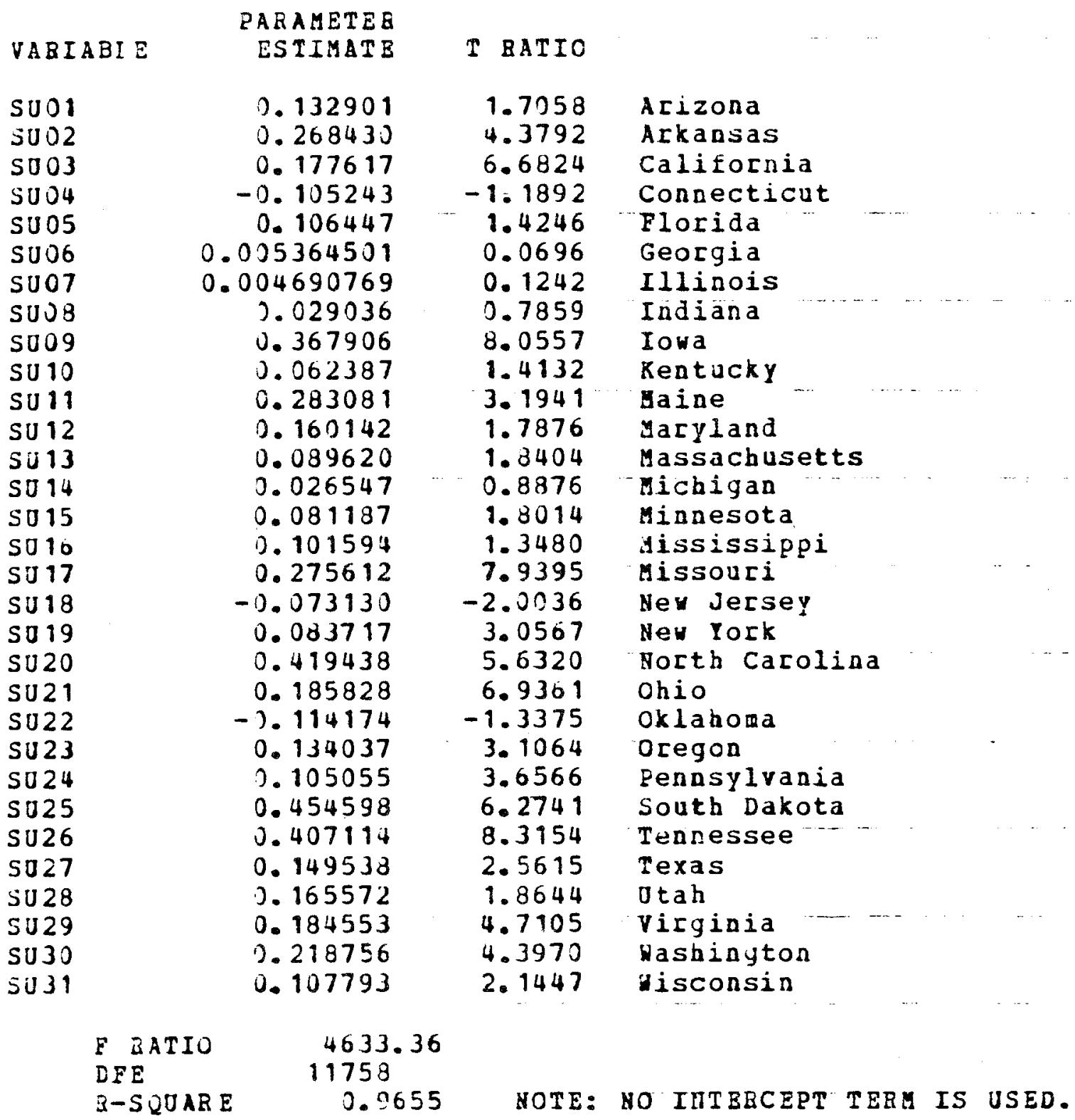


(3) The third set of dumies refers to aggregate occupations cross-classified by aggregate industries:

$\begin{array}{ccr}\text { PARIABIE } & \begin{array}{r}\text { PARAMEEB } \\ \text { ESTIMATE }\end{array} & \text { T BATIO } \\ \text { Durables } & & \\ \text { IOU01 } & -0.161345 & -2.7482 \\ \text { IOU02 } & 0.017291 & 0.2213 \\ \text { IOU03 } & 0.106036 & 3.9576 \\ \text { IOU04 } & 0.223627 & 8.1542 \\ \text { IOU05 } & 0.153847 & 1.9201\end{array}$

professional or managerial

clerical and sales

craftsmen, foremen and kindred

operatives and kindred

IOU 05

0.153847

laborers and service vorkers

Non-durables manufacturing

$\begin{array}{lrr}\text { IOUU6 } & -0.222012 & -2.4278 \\ \text { IOU07 } & 0.020362 & 0.2382 \\ \text { IOUUB } & 0.102038 & 1.7847 \\ \text { IOU } 09 & 0.258602 & 6.3823 \\ \text { IOU10 } & 0.136277 & 1.2682\end{array}$

professional or magerial

clerical and sales

craftsmen. foremen and kindred operatives and kindred

laborers and service yorkers

Construction

$\begin{array}{llr}\text { IOU } 11 & 0.380947 & 4.0230 \\ \text { IOU } 12 & 0.394693 & 11.8224 \\ \text { IOU } 13 & 0.341520 & 3.8748\end{array}$

professional or managerial

craftsmen, foremen and kindred

laborers and service workers

Transportation, comunication, public utilities

IOU 14

IOU 15

IOU 16

IOU 17

IOU 18
0.035351

$-0.00629608$

0.184263

0.231402

0.318112
0.5346

$-0.0954$

4. 2493

4. 0272

3. 1273 professional or managial

clerical and sales

craftsmen, foremen and kindred

operatives and kindred

laborers and service workers

Wolesale and retail trade
IOU 19
IOU 20
0.073211
0.123114
1.0787
2.2794
professional or managerial
IOU 21
0.359201
5.9317
clerical and sales
IOU 22
0.412222
5. 1120
operatives and kindred
laborers and service vorkers

Educational services, private or public
IOU 23
0.171116
4. 3852
professional or managerial

Those and all other services

I0024 $0.068333^{2} 2.3846^{-\cdots}$ all occupational categories, except I023

Governinent, excl medical or educational services; NA whether other

I 0025

IOU 26

0.148524

IOU 27

0.145901

2. 3907

1. 9485

professional or managerial

0.247951

3.7062

clerical and sales

craftsmen, foremen and kindred

$\begin{array}{ll}\text { RATIO } & 4083.84 \\ \text { DPE } & 8284 \\ \text { B-SQUABE } & 0.9688\end{array}$

NOTE: WO INTRRCERT TERH IS USEO. 
Table A7

Determinants of In-Firm Training on Current Job

NLS Young Men, 1969-1971 White, Educ 12

\begin{tabular}{l|rlr} 
Variable & $\beta$ & $t$ \\
\hline Educ & .013 & $(7.2)$ & .039 \\
$\mathrm{X}_{2}$ & .009 & $(1.4)$ & .015 \\
$\mathrm{X}^{2}$ & -.001 & $(.9)$ & -.0005 \\
$\mathrm{~T}$ & .055 & $(3.4)$ & \\
$\mathrm{T}^{2}$ & -.005 & $(2.1)$ & \\
Mar & .018 & $(1.1)$ \\
Hlth & -.044 & $(1.3)$ \\
Union & .014 & $(.7)$ \\
Min. Wage* & -.196 & $(2.7)$ \\
& &
\end{tabular}

MID, A11 Men, 1973-1975 White, Educ $\leqq 12$

\begin{tabular}{ll}
\multicolumn{1}{c}{$\beta$} & $t$ \\
-.0007 & $(.01)$ \\
-.001 & $(0)$ \\
-.001 & $(0)$ \\
-.005 & $(.7)$ \\
.00 & $(.3)$ \\
.014 & $(.1)$ \\
.005 & $(26.8)$ \\
-.164 & $(2.4)$ \\
-.220 & \\
$\mathrm{R}^{2}=.08$
\end{tabular}

* Inverse of one plus state wage differential, multiplied by coverage (see Leighton and Mincer, 1980). 